\title{
Highlights
}

- Chronic exposure to below-threshold doses of UV-B radiation induce cataract in mice

- Both wild-type and Epha2 heterozygous mice develop UV-B dose-dependent cataract

- Recovery time after UV-B exposure and Epha2 genotype influence cataract severity

- Lens epithelial cell proliferation underlies UV-B induced cataract in mice

- Partial Epha2 deficiency favours against UV-B induced ongoing damage to the lens 


\section{Epha2 genotype influences ultraviolet radiation induced cataract in mice}

Short title: UV-B and EPHA2 interaction in cataract

Alpana Dave ${ }^{1 \uparrow, ~ J a m i e ~ E . ~ C r a i g ~}{ }^{1 \uparrow}$, Karina Skrzypiec ${ }^{1}$, Stephen Quinn², Mary Barnes ${ }^{3}$, Nick Di

Girolamo $^{4}$, David A. Mackey ${ }^{5,6}$, Kathryn P. Burdon ${ }^{1}$, Robb U. de Iongh $^{7}$, Shiwani Sharma ${ }^{1 *}$

${ }^{1}$ Department of Ophthalmology, ${ }^{3}$ Flinders Centre for Epidemiology and Statistics, Flinders

University, Bedford Park, South Australia, Australia.

${ }^{2}$ Department of Statistics, Data Science and Epidemiology, Swinburne University of

Technology, Melbourne. Australia.

${ }^{4}$ Department of Pathology, School of Medical Sciences, University of New South Wales, Sydney, Australia.

${ }^{5}$ Centre for Ophthalmology and Visual Science, Lions Eye Institute, University of Western Australia, Perth, Australia.

${ }^{6}$ Menzies Institute for Medical Research, University of Tasmania, Hobart, Australia, ${ }^{7}$ Ocular Development Laboratory, Anatomy \& Neuroscience, University of Melbourne, Parkville, Australia.

*Corresponding author

Email: shiwani.sharma@flinders.edu.au (SS)

TThese authors contributed equally to this work.

Funding: This work was funded by the National Health and Medical Research Council (NHMRC), Australia (grant\# GNT11009955), the Flinders Medical Centre Foundation and 
the Flinders University, South Australia, Australia. JEC and KPB are recipients of NHMRC Practitioner and Senior Research Fellowships, respectively.

Keywords: Epha2, UV-B radiation, age-related cataract, gene-environment interaction, mouse model, histological analysis, molecular mechanism 


\section{Abstract}

Age-related cataract is the major cause of blindness worldwide. Both genetic and environmental factors contribute to the disease. Genetic variation in the Ephrin type-A receptor 2 (EPHA2) gene is associated with the risk of age-related cataract in multiple populations, and exposure to ultraviolet-B (UV-B) radiation is a well-established risk factor for the disease. Epha2 knockout and UV-B radiation independently lead to cataract in mice, and UV-B radiation reportedly alters EPHA2 expression in cultured cells. We hypothesised that an interaction between UV-B radiation exposure and Epha2 signalling may influence

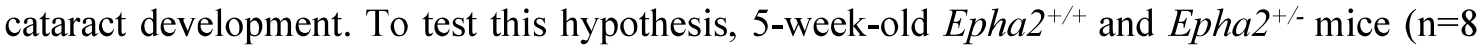
per group) were exposed to repeated below-threshold doses of UV-B radiation $(0.0125$ to $0.05 \mathrm{~J} / \mathrm{cm}^{2}$ ), before development of Epha2-mediated cataract. Cataract development was monitored after termination of exposure and at least one month later. Histological analysis of exposed and unexposed lenses was performed to assess pathological changes, and gene expression analysis to investigate the mechanism underlying cataract. Both $E p h a 2^{+/+}$and Epha2 $^{+/-}$mice developed UV-B dose-dependent anterior polar cataract; cataract severity in both genotypes of mice exposed to either 0.025 or $0.05 \mathrm{~J} / \mathrm{cm}^{2} \mathrm{UV}-\mathrm{B}$ was significantly higher than that in matched unexposed mice $(p<0.05)$. Histological analysis of lenses of both genotypes of mice exposed to 0.025 or $0.05 \mathrm{~J} / \mathrm{cm}^{2} \mathrm{UV}-\mathrm{B}$ radiation consistently revealed disruption of the lens architecture. A month after the exposure, cataract severity increased in Epha2 $^{+/+}$mice treated with the highest dose of UV-B radiation $(p=0.03)$ but remained unchanged in $E p h a 2^{+/}$mice. Gene expression analysis of lenses of both genotypes of mice

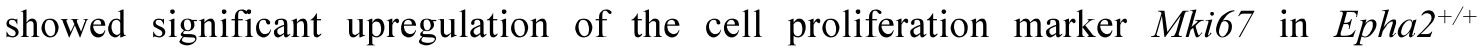
( $p=0.036)$ but not in Epha2 ${ }^{+/}$mice exposed to the highest dose of UV-B radiation compared to matched unexposed mice. In conclusion, this study suggests that repeated exposure to doses of UV-B radiation lower than the single minimum dose required for 
inducing cataract leads to cataract in wild-type and Epha2 heterozygous knockout mice. Furthermore, this study indicates, for the first time, a potentially favourable effect of partial Epha2 deficiency against UV radiation-induced damage in the lens. 


\subsection{Introduction}

Cataract presents rarely at birth (congenital cataract), or during early childhood, but is more common after the age of $\sim 45$ years (age-related cataract) (Shiels and Hejtmancik, 2007). Agerelated cataract accounts for more than $40 \%$ of cases of blindness worldwide, mostly in developing countries (Abraham et al., 2006, Lee and Afshari, 2017). A complex interaction of genetic and environmental factors is thought to contribute to the disease risk (Abraham et al., 2006). Ultraviolet (UV) radiation exposure, mainly from sunlight, is one of the wellestablished risk factors for developing age-related cataract (West and Valmadrid, 1995, Abraham et al., 2010, McCarty et al., 2000).

UV radiation reaching the earth comprises UV-A (400-315 nm), UV-B (315-280 $\mathrm{nm})$ and UV-C (280-100 nm) (Michael, 2000). All UV-C and most UV-B is absorbed by the ozone layer, while some UV-B and all of the UV-A spectrum reach ground level (Michael, 2000, Lucas, 2011, Modenese et al., 2018). A large proportion of UV-B reaching the human eye is absorbed by the cornea and the lens absorbs the remainder (McCarty and Taylor, 2002), whereas a small amount of UV-A entering the eye is absorbed by the cornea and some by the lens, the majority reaches the retina (Lucas, 2011). Exposure to UV-B has been associated with age-related cortical cataract development in humans but UV-A has not been considered cataractogenic (West et al., 1998, McCarty et al., 2000, Taylor et al., 1988). However, some studies support a role of UV-A in cataract development in humans (Roberts, 2011). Regardless of whether UV-A or UV-B contributes to cataract, population-based studies in countries such as the U.S.A., Australia, France and Iceland have associated day-to-day UV radiation exposure with increased risk of cataract development (Cruickshanks et al., 1992, McCarty et al., 2000, Delcourt et al., 2000, Katoh et al., 2001). Exposure to UV radiation can also lead to cataract in animals. However, due to differences in corneal thickness and general anatomy of the eye, the amount of UV radiation transmitted to the lens is different in animals 
compared to humans (Dillon et al., 1999). Despite these differences, animals have been used as models to understand the effect of UV radiation exposure on the ocular lens and on cataract development. Rodent models have been used to investigate the doses of UV radiation sufficient to cause cataract and mechanisms of damage to the crystalline lens (Galichanin et al., 2012, Soderberg, 1990, Michael et al., 1998b, Michael et al., 2000). In rodents, similar to humans, UV-B is more cataractogenic than UV-A (Wegener, 1994).

The majority of the studies in rodents have demonstrated damage to the ocular lens caused by a single exposure to an above-threshold dose of UV-B (Michael, 2000, Galichanin et al., 2010, Ayala et al., 2000b, Galichanin et al., 2012), with threshold dose being the minimum dose sufficient to cause cataract. These studies are useful indicators of the effect of exposure to relatively higher doses of UV radiation on the ocular lens experienced by certain individuals due to their professions such as welders, radiation workers and farmers. Most humans experience repeated exposure to lower levels of UV radiation from the atmosphere. To date, only a few studies have investigated the effects of repeated below-threshold doses of UV-B radiation on the lens (Galichanin et al., 2014, Wegener, 1994) that are relevant to the human population.

Genetic factors also influence age-related cataract development in humans. Mutations or common variants in genes including Galactose-1-phosphate uridylyltransferase (GALT), Heat shock factor 4 (HSF4), Crystallin alpha A (CRYAA), Potassium voltage-gated channel subfamily A member regulatory beta subunit 1 (KCNAB1), Superoxide dismutase 1 (SOD1), Xeroderma pigmentosum complementation group $D(X P D)$ and Idoleamine 2,3 dioxygenase (IDO) have been linked with age-related cataract in certain populations but these findings are yet to be replicated in other populations (Shi et al., 2008, Bhagyalaxmi et al., 2009, Karas et al., 2003, Zhang et al., 2011, Mamata et al., 2011, Padma et al., 2011, Liao et al., 2014). Only genetic variation in the Ephrin type-A receptor 2 (EPHA2) gene has been reproducibly 
associated with age-related cataract in humans in multiple populations (Jun et al., 2009, Shiels et al., 2008, Zhang et al., 2009). Variants in this gene are associated with the risk of cortical, nuclear and posterior subcapsular cataract in different populations (Jun et al., 2009, Sundaresan et al., 2012, Shiels et al., 2008). Additionally, highly penetrant mutations in the EPHA2 gene cause congenital cataract (Kaul et al., 2010, Dave et al., 2013, Zhang et al., 2009, Shentu et al., 2013, Shiels et al., 2008). EPHA2 belongs to the Eph receptor tyrosine kinase family (Pasquale, 2008). These molecules interact with Ephrin ligands to bring about cell signalling. This signalling plays an important role in cell adhesion and repulsion, cell survival, cell migration and epithelial to mesenchymal transformation. Epha2 is expressed in epithelia during development and throughout life and is involved in maintaining epithelial homeostasis. It is upregulated in various types of tumors and is a target for drug development. Apart from its involvement in cataract in humans, knockout of the orthologous Epha2 gene in mice leads to development of age-related cortical cataract (Jun et al., 2009, Shi et al., 2012, Cheng et al., 2013). Thus EPHA2 is an important gene in cataract, and Epha2 signalling is important for maintaining transparency of the mammalian lens.

Interestingly, UV radiation treatment has been reported to increase Epha2 expression levels in human and mouse melanocytes, keratinocytes and embryonic fibroblast (MEF) cells (Zhang et al., 2008) indicating that UV radiation interacts with the EPHA2 gene and possibly Epha2 signalling. Thus we hypothesised that an interaction between UV exposure and Epha2 signalling may influence cataract development. In the present study, we tested this hypothesis using the Epha2 knockout mouse model in the context of repeated exposures to belowthreshold doses of UV-B radiation, relevant to the human population. 


\subsection{Materials and Methods}

\subsubsection{Ethics statement}

All experimental procedures in animals and post-procedural animal welfare conformed to the ARVO Statement for the Use of Animals in Ophthalmic and Vision Research, and the Australian Code of Practice for the Care and Use of Animals for Scientific Purposes (2004) and were approved by the Animal Welfare Committee, Flinders University, Adelaide, Australia (Approval number 796/11). All eye examinations were performed under anaesthesia.

\subsubsection{Animals}

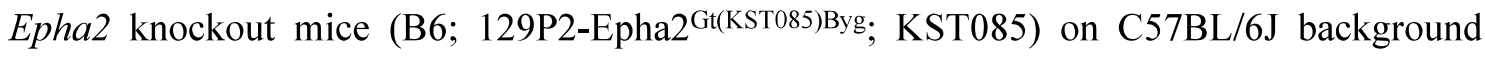
were purchased from the Mutant Mouse Regional Resource Center, University of Missouri, U.S.A. The mice were generated using the secretory trap method (Leighton et al., 2001,

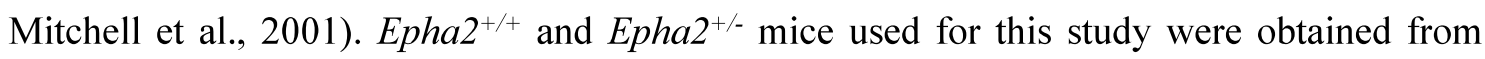
crosses between $\mathrm{Epha2}^{+/-} \times \mathrm{Epha2}^{+/-}, \mathrm{Epha2}^{+/-} \times \mathrm{Epha2}^{+/+}, \mathrm{Epha2}^{+/+} \times \mathrm{Epha2}^{+/+}$and Epha2 $2^{-/-}$ $\times$ Epha2 $^{+/+}$mice.

\subsubsection{Genotyping}

The 129P2 strain, used for generation of the Epha2 knockout mouse, carries a deletion mutation in the Beaded filament structural protein 2 (Bfsp2) that is known to cause anterior polar cataract (Sandilands et al., 2004, Alizadeh et al., 2004). The cataract-causing allele was eliminated by polymerase chain reaction (PCR)-based Bfsp2 genotyping in the first two generations and selecting non-mutation carrier mice as breeders for colony maintenance.

For genotyping the Bfsp2 mutation, genomic DNA from mouse tail tip or ear notch was extracted in lysis buffer (0.1 M Tris- $\mathrm{HCl} \mathrm{pH} 8.3,0.2 \mathrm{M} \mathrm{NaCl}, 0.005 \mathrm{M}$ EDTA, 0.2\% SDS, 
$100 \mu \mathrm{g} / \mathrm{ml}$ Proteinase K), precipitated using isopropanol and resuspended in MilliQ water. Genotyping was performed as previously described (Alizadeh et al., 2004) using genespecific primers (Table 1) and genomic DNA template. PCR was performed in the presence of Hot Star Taq Plus DNA polymerase (Qiagen Pty Ltd, VIC, Australia). The enzyme was activated at $95^{\circ} \mathrm{C}$ for 5 minutes, followed by 35 cycles of denaturation at $95^{\circ} \mathrm{C}$ for 30 seconds, annealing at $68^{\circ} \mathrm{C}$ for 30 seconds and extension at $72^{\circ} \mathrm{C}$ for 30 seconds; a postextension cycle at $72^{\circ} \mathrm{C}$ for 1 minute was followed by incubation at $4{ }^{\circ} \mathrm{C}$ for 5 minutes. The products were analysed by agarose gel electrophoresis and difference in size of the PCR product, $905 \mathrm{bp}$ for wild-type allele and $386 \mathrm{bp}$ for mutant allele, distinguished between the three genotypes. All mice used in the present work were wild-type for Bfsp2.

To determine the status of Epha2 knockout in offspring, Epha2 genotyping was performed using primers M30828F, M30828WTR and M30828MutR (Table 1) and PCR conditions described above except annealing was performed at $61^{\circ} \mathrm{C}$. PCR products were analysed by agarose gel electrophoresis. A PCR product of $200 \mathrm{bp}$ and $400 \mathrm{bp}$ corresponding to the wild-

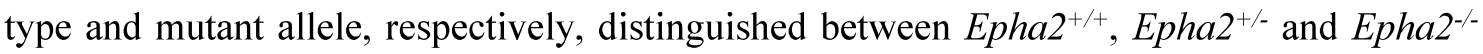
mice.

Table 1: Sequences of primers used in this study

\begin{tabular}{|l|l|l|}
\hline Gene & Primer Name & Sequence 5'>3' \\
\hline Genotyping & TGGGGTTGGGCTAGAAATCTCAGA \\
\hline $\boldsymbol{B}$ ssp2 & CP49fwd & \\
\cline { 2 - 3 } & CP49WTR & TACTCAAAAGGCAGTAGTCCCTGC \\
\cline { 2 - 3 } & CP49MutR & AGCCCCTACGACCTGATTTTTGAG \\
\hline \multirow{2}{*}{ ppha2 } & M30828F & CACCTCACTCAGTATAGTGCTCCA \\
\cline { 2 - 3 } & M30828WTR & CGTCTTCCCAGTCATACTCTACTT \\
\end{tabular}




\begin{tabular}{|c|c|c|}
\hline & M30828MutR & CCATACAGTCCTCTTCACATCCAT \\
\hline \multicolumn{3}{|c|}{ Gene expression analysis } \\
\hline \multirow[t]{2}{*}{ Mki67 } & Mki67-F & AGAGCTAACTTGCGCTGACTG \\
\hline & Mki67-R & TCTTGAGGCTCGCCTTGATG \\
\hline \multirow[t]{2}{*}{ Acta2 } & mActa2-F & CCTTCGTGACTACTGCCGAG \\
\hline & mActa2-R & GTCAGCAATGCCTGGGTACAT \\
\hline \multirow[t]{2}{*}{ Epha2 } & mEpha2Ex5Fwd & GAGCGTGCGCTATTCAGAAC \\
\hline & mEpha2Ex6Rev & GTACTTCCACACACGGCTCT \\
\hline \multirow[t]{2}{*}{$B 2 m$} & mB2mqperFwd & ATTCACCCCCACTGAGACTG \\
\hline & mB2mqpcrRev & TGC TAT TTC TTC TGC GTG C \\
\hline
\end{tabular}

\subsubsection{UV-B exposure}

The UV-B exposure station used for exposing animals was designed and built in-house (Department of Biomedical Engineering, Flinders Medical Centre, Adelaide, Australia). Two 20 W UV-B broadband (290-315 nm) fluorescent lamps (Philips TL 20 W/12 RS SLV) mounted under the top shelf of a two-shelf trolley served as the UV-B radiation source. The UV-B lamps were covered with a $0.25 \mathrm{~mm}$ thick polytetrafluoroethylene (PTFE, Teflon) layer that attenuated $48 \%$ of UV-B to minimise corneal damage upon exposure. The UV-B radiation dose was recorded from a fixed distance $(43 \mathrm{~cm})$ using a UVX digital radiometer attached to the UVX series sensor (UVP Inc, CA, U.S.A.). The recorded output was logged on a 0 to $2.5 \mathrm{~V}$ Tiny Talk data logger (Gemini Data Loggers Ltd, West Sussex, U.K.) for calculating the duration of exposure. Exposure time and the administered dose were controlled with a timer.

For UV-B exposure, mice were individually placed in a polycarbonate animal holder and restrained with a wire mesh cover. The same mesh was placed on the UVX sensor for estimation of 'actual' administered UV-B radiation dose. Animals were exposed to UV-B radiation from a distance of $43 \mathrm{~cm}$, placed on bottom shelf of the trolley. 
The Maximum Tolerable Dose $\left(\mathrm{MTD}_{2.3: 16}\right)$, i.e. the threshold dose of UV-B for avoidance of cataract in $\mathrm{C} 57 \mathrm{BL} / 6 \mathrm{~J}$ mice, is $0.29 \mathrm{~J} / \mathrm{cm}^{2}$ (Meyer et al., 2008, Soderberg et al., 2002). The doses of UV-B radiation administered in this study $\left(0.0125-0.05 \mathrm{~J} / \mathrm{cm}^{2}\right)$ were lower than the threshold dose (below-threshold) and the lowest administered in rodent models to date (Michael and Brismar, 2001) except the lowest daily dose administered by Galichanin et.al (Galichanin et al., 2014). Five-week-old $\mathrm{Epha2}^{+/+}$and $E p h a 2^{+/-}$mice (n=8 per group) were exposed to $0.0125,0.025$ or $0.05 \mathrm{~J} / \mathrm{cm}^{2}$ of UV-B radiation twice a week, every third and fourth day, for a total of seven times. The duration of each treatment to achieve the desired dose ranged from $6-11,13-23$ and $27-46$ minutes for $0.0125,0.025$ or $0.05 \mathrm{~J} / \mathrm{cm}^{2} \mathrm{UV}-\mathrm{B}$, respectively. For an intended dose of $0.0125 \mathrm{~J} / \mathrm{cm}^{2}$, the actual administered dose ranged from $0.0112-0.0137 \mathrm{~J} / \mathrm{cm}^{2}$, for $0.025 \mathrm{~J} / \mathrm{cm}^{2}$ from $0.022-0.0268 \mathrm{~J} / \mathrm{cm}^{2}$, and for $0.05 \mathrm{~J} / \mathrm{cm}^{2}$ from $0.045-0.055 \mathrm{~J} / \mathrm{cm}^{2}$. To avoid gender bias, equal numbers of males and females were included in each group, except $E p h a 2^{+/+}$mice exposed to $0.025 \mathrm{~J} / \mathrm{cm}^{2} \mathrm{UV}-\mathrm{B}$ (6 males and 2 females). Similar size groups of age- and gender- matched unexposed $E p h a 2^{+/+}$and $E p h a 2^{+/-}$mice were used as controls. Cataract development was monitored 24-48 hours and 4-7 weeks after the last exposure.

\subsubsection{Ophthalmic examination}

Cataract grading was performed in anesthetized mice. For ophthalmic examination, mice were mildly sedated by isofluorane inhalation and then anesthetized with an intraperitoneal injection of $75 \mathrm{mg} / \mathrm{kg}$ ketamine (Lyppard Australia Pty. Ltd., SA, Australia) and $0.01 \mathrm{mg}$ medetomidine (Troy Laboratories Pty. Ltd., NSW, Australia). Mydriasis was induced by topical administration of $1 \%$ tropicamide (Bausch \& Lomb Pty. Ltd., NSW, Australia). Examination was performed on a photo-slit lamp biomicroscope (Topcon Medical Systems Inc., NJ, U.S.A.) in a masked fashion and cataract graded in each eye of an animal. Cortical 
cataract was graded according to the Lens Opacities Classification System (LOCS) III (Chylack et al., 1993, Sparrow et al., 1986). As a standard system for grading anterior polar cataract was unavailable, we developed a grading system based on the size of anterior polar lens opacity for measuring severity of this form of cataract. Anterior polar cataract was graded on a 4-point scale from $0-3$, with 0 representing no cataract, 1 mild, 2 moderate and 3 severe cataract (Fig 1). Both eyes of all mice were examined within 5-10 minutes after anesthesia. The observations were recorded by digital photography at $40 \times$ magnification using the EZ Capture software (Topcon Medical Systems Inc., NJ, U.S.A.). Three images of each eye, with 1) diffuse illumination, 2) cross-section illumination of the lens, and 3) retroillumination were captured, all at maximum flash intensity. For diffuse illumination imaging, the slit height was set at 5 with widest slit width, and the light angle was set at $35^{\circ}$. This enabled documentation of any cortical lens opacity. For capturing cross-section illumination of the lens, the slit height and slit width were set at $2 \mathrm{~mm}$ each, and the light angle was set at $45^{\circ}$. This showed any anterior opacity in the lens. Retroillumination image was captured with the slit height and slit width set at $5 \mathrm{~mm}$ each. This revealed any total lens opacity and corneal aberrations. After the first examination, mice were revived with an intraperitoneal injection of $0.05 \mathrm{mg}$ atipamizole (Troy Laboratories Pty. Ltd., NSW, Australia).

\subsubsection{Tissue collection and histological analysis}

For tissue collection, mice were euthanized and whole eyes enucleated under an ophthalmic microscope, fixed in 10\% neutral buffered formalin for 24-72 hours and paraffin embedded. Alternatively, ocular lens was dissected and snap frozen for later use. For histology, $7 \mu \mathrm{m}$ thick serial sections were stained with hematoxylin and eosin and imaged on a Brightfield Olympus BX50 microscope equipped with QImaging RTV 5 megapixel Digital Camera 
(QImaging, BC, Canada) and QCapture software (QImaging, BC, Canada) using a 20× objective.

\subsubsection{Gene expression analysis}

Total RNA from mouse lens was extracted using the RNeasy Mini kit (Qiagen Pty Ltd, VIC, Australia) as per the manufacturer's protocol with Proteinase K $(400 \mu \mathrm{g})$ digestion for 10 minutes. For gene expression analysis in UV-exposed and unexposed mice, lenses of two mice of the same gender within a group were pooled for RNA extraction. Genomic DNA was removed by Ambion ${ }^{\mathrm{TM}}$ DNase I (RNase-free; Thermo Fisher Scientific Australia Pty Ltd, VIC, Australia) treatment as recommended. From $1 \mu \mathrm{g}$ total RNA, cDNA was synthesized using Superscript III reverse transcriptase and random hexamers (Invitrogen, Life Technologies Corporation, CA, USA). Relative expression of Mki67, Acta2 and Epha2 genes in UV-B treated and untreated lenses was analysed by semi-quantitative RT-PCR; expression was normalised to $B 2 m$ expression. Messenger RNA of each gene was amplified from cDNA template using mouse-specific primers (Table 1) and Hot Star Taq Plus DNA polymerase. PCR conditions were, enzyme activation at $95^{\circ} \mathrm{C}$ for 3 minutes, followed by cycles of denaturation at $95^{\circ} \mathrm{C}$ for 30 seconds, annealing for 30 seconds and elongation at $72^{\circ} \mathrm{C}$ for 30 seconds, and a final elongation at $72{ }^{\circ} \mathrm{C}$ for 5 minutes. Annealing temperature for amplification of Mki67 mRNA was $65^{\circ} \mathrm{C}$, for Acta2 and Epha2 $60^{\circ} \mathrm{C}$, and for B2m $62^{\circ} \mathrm{C}$. Mki67, Acta2, Epha2 and B2m mRNA were amplified for 39, 25, 32 and 40 cycles, respectively. Mki67 mRNA was amplified in the presence of Q solution (Qiagen Pty Ltd, VIC, Australia). Amplified products were analysed by agarose gel electrophoresis and band intensities quantified using the ImageJ software. For Epha2 gene expression analysis in different genotypes of mice, both lenses of an animal were pooled for RNA extraction and $0.74 \mu \mathrm{g}$ total RNA used for cDNA synthesis; $B 2 m$ expression served as the housekeeping control. 


\subsubsection{Statistical analysis}

Statistical analyses of ophthalmic data were performed using IBM Statistical Package for the Social Science (SPSS) Statistics 19 and Stata 14.1 (StataCorp, College Station, Texas, USA). The primary endpoints were average anterior cortical cataract and average anterior polar cataract grades in both eyes of an animal. To determine agreement of cataract grades between the two eyes of each animal Intraclass Correlation Coefficient (ICC) was calculated according to the two-way random-effects model using the icc function from the irr package in R (Team, 2013).

The effect of UV-B radiation on cataract severity in a genotype at a time-point was analysed using Mann-Whitney $U$ test. The difference in cataract severity between genotypes upon UVB exposure at each time-point was also analysed by Mann-Whitney $U$ test. The difference in cataract severity between the two time-points in a genotype was analysed using Wilcoxon Signed Ranks test. No adjustment for multiple comparisons was made as the study was not powered to detect a specific effect. As the data were not normally distributed, adopting a conservative approach, the results at each time-point are presented as median and interquartile range. The results of comparison between time-points are presented as mean and standard error of the mean. Gene expression data was analysed by Student's $t$-test using the GraphPad Prism 7 software. A $p$ value less than or equal to 0.05 (two-tailed) was deemed to be statistically significant.

\subsection{Results}

In this study, we determined the cumulative effect of repeated exposures to below-threshold doses of UV-B radiation on cataract development in wild-type and Epha2 heterozygous knockout mice. Multiple below-threshold doses of UV-B radiation were administered 
through whole-body exposure in wakeful mice to mimic repeated exposure of humans to UV radiation from sunlight. The Epha2 $2^{-/}$mice on $\mathrm{C} 57 \mathrm{BL} / 6 \mathrm{~J}$ background develop severe bilateral cortical cataract by 4-5 months of age and Epha2 ${ }^{+-}$mice at a later age (to be published elsewhere). To avoid confounding effects of genetically induced cataract, Epha2 ${ }^{+/}$mice at a younger age with clear lenses, were used for the study. Expression levels of Epha2 between

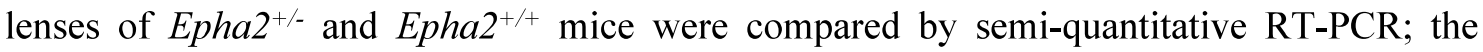
expression level of Epha2 gene in wild-type mouse lens was too low for analysis by real-time RT-PCR. Epha2 ${ }^{+/}$mice generally expressed lower levels of Epha2 mRNA in the lens than wild-type mice (Fig 2). Thus instead of using Epha2-/- mice that completely lack Epha2 expression in the lens, we used $E p h a 2^{+/}$mice to test our hypothesis. Both wild-type and Epha2 ${ }^{+/-}$mice were repeatedly exposed to $0.0125,0.025$ or $0.05 \mathrm{~J} / \mathrm{cm}^{2}$ of UV-B radiation and cataract development monitored as described in Section 1.2.5.

The corneas of mice exposed to $0.05 \mathrm{~J} / \mathrm{cm}^{2}$ and $0.025 \mathrm{~J} / \mathrm{cm}^{2}$ doses of $\mathrm{UV}$-B radiation showed slight punctate epithelial erosion at the first ophthalmic examination that did not interfere with grading of cataract (not shown). Corneal epithelial erosion had resolved at the second eye examination, indicating repair of the original epitheliopathy. Mice exposed to 0.0125 $\mathrm{J} / \mathrm{cm}^{2} \mathrm{UV}-\mathrm{B}$ did not develop any observable corneal damage.

\subsubsection{Dosage effect of UV-B radiation on cataract development}

After termination of UV-B exposure and 4-7 weeks later, depending upon the dose of UV-B administered, wild-type and Epha2 ${ }^{+/}$mice developed mild anterior cortical cataract with or without anterior polar cataract. Each type of cataract, cortical and polar, was separately graded and analysed at each time-point. Both unexposed mice of each genotype, and mice exposed to $0.0125,0.025$ and $0.05 \mathrm{~J} / \mathrm{cm}^{2} \mathrm{UV}-\mathrm{B}$ radiation developed mild cortical cataract after the final exposure and 4-7 weeks later (Table 2). The difference in cortical cataract 
severity between unexposed and exposed mice of each genotype at both the time-points was not significant. Thus, mild cortical cataract was considered to be temporarily induced due to anaesthesia rather than UV-B treatment and was not further analysed. In contrast, anterior polar cataract was present in UV-exposed mice of both genotypes at both time-points and was absent in all except one unexposed mouse (Fig 3 and 4). Furthermore, the severity of anterior polar cataract correlated with the dose of UV-B radiation exposure in mice of each genotype. Thus, anterior polar cataract was considered to be UV-B induced and was analysed in detail. The ICC of $0.85(95 \% \mathrm{CI}=0.80-0.89)$ indicated that cataract grades between the two eyes of each animal were highly consistent. 
Table 2: Comparison of anterior cortical cataract severity in $\mathrm{Epha2}^{+/+}$and $\mathrm{Epha2}^{+/-}$mice exposed to different doses of UV-B radiation.

\begin{tabular}{|c|c|c|c|c|c|}
\hline \multirow[t]{2}{*}{$\begin{array}{l}\text { Dose of } \\
\text { UV-B J/cm² } \\
\text { (Group size) }\end{array}$} & \multicolumn{2}{|c|}{ Epha2 ${ }^{+/+}$} & \multicolumn{2}{|c|}{ Epha2 $+/$} & \multirow[t]{2}{*}{\begin{tabular}{|l}
$p$ value \\
$\left(\right.$ Epha2 $^{+/+}$ \\
versus \\
Epha2 $\left.^{+/}\right)$
\end{tabular}} \\
\hline & Median (IQR) & $p$ value $^{\dagger}$ & Median (IQR) & $p$ value $^{\dagger}$ & \\
\hline \multicolumn{6}{|c|}{ 24-48 hours after final exposure } \\
\hline $\boldsymbol{0}(\mathrm{n}=9)$ & $1.5(1.5-2)$ & - & $2(1.5-2.13)$ & - & 0.48 \\
\hline $0.0125(\mathrm{n}=8)$ & $2(1.25-2)$ & 0.88 & $2(1.75-2)$ & 0.96 & 0.38 \\
\hline $0.025(n=8)$ & $2(1.5-2.25)$ & 0.39 & $2(1.88-2)$ & 0.82 & 0.57 \\
\hline $0.05(n=8)$ & $2(1.88-2)$ & 0.24 & $2(1.63-2)$ & 0.96 & 0.85 \\
\hline \multicolumn{6}{|c|}{ 4-7 weeks after final exposure } \\
\hline $\mathbf{0}(\mathrm{n}=9)$ & $2(1.5-2)$ & - & $1.5(1.13-2)$ & - & - \\
\hline $0.0125(n=8)$ & $2(1.63-2.13)$ & 0.45 & $1.63(1.5-2)$ & 0.49 & 0.36 \\
\hline $0.025(n=8)$ & $2(1.63-2.13)$ & 0.51 & $1.63(1.5-1.75)$ & 0.67 & 0.10 \\
\hline $0.05(n=8)$ & $1.75(1.5-2.13)$ & 0.76 & $1.88(1.5-2)$ & 0.31 & 0.95 \\
\hline
\end{tabular}

Median grade of cataract in each group at the two time-points is shown. $p$ values of comparison between unexposed and exposed group of each genotype, and comparison between the two genotypes exposed to a dose of UV-B radiation are indicated. Comparisons were performed using Mann-Whitney $U$ test. IQR, inter-quartile range.

$\dagger p$ values represent difference between a given dose $(0.0125,0.025$ or 0.05$)$ versus no dose (0) at a time-point. 
At the first time-point (24-48 hours after the last exposure), mild (grade 1) anterior polar

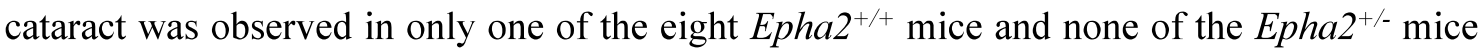
exposed to $0.0125 \mathrm{~J} / \mathrm{cm}^{2}$ UV-B radiation (Fig 3 and 4). Thus, there was no significant difference in cataract severity between unexposed and mice exposed to the lowest dose of UV-B radiation (Table 3). Of the mice exposed to $0.025 \mathrm{~J} / \mathrm{cm}^{2} \mathrm{UV}-\mathrm{B}$, three out of eight $E p h a 2^{+/+}$and five out of eight Epha2 ${ }^{+/-}$mice displayed anterior polar cataract at the first time-point $\left(E p h a 2^{+/+}\right.$, median $(\mathrm{IQR})=0(0-1.25) ; E p h a 2^{+/-}$, median $(\mathrm{IQR})=0.75(0-1.75)$; Table 3 and Fig 3 and 4). The exposed wild-type mice compared to unexposed mice showed only a borderline significant increase in cataract severity $(p=0.051$, Table 3$)$. However, the exposed $E p h a 2^{+/-}$mice displayed significantly greater increase in cataract severity than their unexposed counterparts ( $p=0.01$, Table 3). Similarly, five out of eight Epha2 ${ }^{+/+}$mice and all Epha2 $2^{+/}$mice exposed to $0.05 \mathrm{~J} / \mathrm{cm}^{2} \mathrm{UV}-\mathrm{B}$ radiation exhibited anterior polar cataract $\left(E p h a 2^{+/+}\right.$, median $(\mathrm{IQR})=0.5(0-1.88) ; E p h a 2^{+/}$, median (IQR) $1.5(1.25-2)$; Table 3 and Fig 3 and 4) compared to no cataract in unexposed mice of each genotype. The difference in cataract severity between exposed and unexposed mice of each genotype was highly significant $\left(\right.$ Epha2 $^{+/+} p=0.007$, Epha2 $^{+/-} p<0.001$; Table 3).

Furthermore, comparison of cataract severity between mice exposed to the lowest and the two higher doses of UV-B showed that in $\mathrm{Epha}^{+/+}$mice exposed to $0.05 \mathrm{~J} / \mathrm{cm}^{2}$ anterior polar cataract severity was significantly greater than in those exposed to $0.0125 \mathrm{~J} / \mathrm{cm}^{2} \mathrm{UV}-\mathrm{B}(p=$ 0.046, Table 3). Epha2 $2^{+/-}$mice exposed to both 0.025 and $0.05 \mathrm{~J} / \mathrm{cm}^{2} \mathrm{UV}-\mathrm{B}$ developed more severe anterior polar cataract than genotype matched mice exposed to $0.0125 \mathrm{~J} / \mathrm{cm}^{2} \mathrm{UV}-\mathrm{B}$ $\left(0.025 \mathrm{~J} / \mathrm{cm}^{2} p=0.011,0.05 \mathrm{~J} / \mathrm{cm}^{2} p<0.001\right.$; Table 3). 
Table 3: Comparison of anterior polar cataract severity in $\mathrm{Epha2}^{+/+}$and $\mathrm{Epha2}^{+/-}$mice exposed to different doses of UV-B radiation.

\begin{tabular}{|c|c|c|c|c|c|c|c|}
\hline \multirow[t]{2}{*}{$\begin{array}{l}\text { Dose of } \\
\text { UV-B J/cm² } \\
\text { (Group size) }\end{array}$} & \multicolumn{3}{|c|}{ Epha2 $+/+$} & \multicolumn{3}{|c|}{$\operatorname{Epha2}^{+/}$} & \multirow[t]{2}{*}{$\begin{array}{l}\text { value } \\
\left(\text { Epha }^{+/+} \text {versus }\right. \\
\left.\text { Epha }^{+/}\right)\end{array}$} \\
\hline & Median (IQR) & $p$ value $\dagger$ & $p$ value & Median (IQR) & $p$ value $\dagger$ & $p$ value & \\
\hline \multicolumn{8}{|c|}{ 24-48 hours after final exposure } \\
\hline $\mathbf{0}(\mathrm{n}=9)$ & $0(0-0)$ & - & - & $0(0-0)$ & - & - & - \\
\hline $0.0125(n=8)$ & $0(0-0)$ & 0.29 & - & $0(0-0)$ & 1 & - & 0.31 \\
\hline $0.025(n=8)$ & $0(0-1.25)$ & $0.05^{*}$ & 0.24 & $0.75(0-1.75)$ & $0.01 * *$ & $0.011^{*}$ & 0.46 \\
\hline $0.05(n=8)$ & $0.5(0-1.88)$ & $0.007 * *$ & $0.046^{*}$ & $1.5(1.25-2)$ & $<0.001 * * *$ & $<0.001 * * *$ & 0.20 \\
\hline \multicolumn{8}{|c|}{ 4-7 weeks after final exposure } \\
\hline $\mathbf{0}(\mathrm{n}=9)$ & $0(0-0)$ & - & - & $0(0-0)$ & - & - & 0.29 \\
\hline $0.0125(n=8)$ & $0(0-0)$ & 0.29 & - & $0(0-0)$ & 0.32 & - & 0.31 \\
\hline $0.025(n=8)$ & $0.13(0-1.88)$ & $0.02 *$ & 0.13 & $0.25(0-1)$ & 0.13 & $0.027^{*}$ & 0.69 \\
\hline $0.05(n=8)$ & $2(1.88-2)$ & $0.001 * * *$ & $0.006^{* *}$ & $1.63(1.38-1.88)$ & $0.002^{* *}$ & $0.001 * * *$ & 0.09 \\
\hline
\end{tabular}


Median grade of cataract in each exposed and unexposed group at the indicated time-points is shown. $p$ values of comparisons between unexposed and exposed groups, between exposed groups of each genotype, and between genotypes are shown. Significance set at $p<0.05$. IQR, inter-quartile range.

$\dagger p$ values represent difference between a given dose $(0.0125,0.025$ or 0.05$)$ versus no dose $(0)$ at a time-point. $\$ p$ values represent difference between a given dose $(0.025$ or 0.05$)$ versus the lowest dose $(0.0125)$ at a time-point.

$*, \mathrm{p} \leq 0.05 ; * *, \mathrm{p} \leq 0.01 ; * * *, \mathrm{p} \leq 0.001$. 
At the second time-point (4-7 weeks after the last exposure), similar to the first time-point,

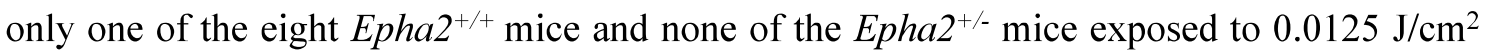
UV-B exhibited anterior polar cataract (Fig 4). The lenses of unexposed Epha2 ${ }^{+/+}$and

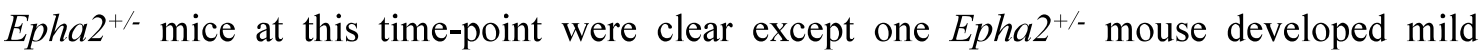
anterior polar cataract (grade 1, Fig 4). Thus, once again, no difference in cataract severity was observed between unexposed and mice exposed to the lowest dose of UV-B radiation (Table 3). Of the mice exposed to $0.025 \mathrm{~J} / \mathrm{cm}^{2} \mathrm{UV}-\mathrm{B}$ radiation, four out of eight mice of each genotype displayed the presence of anterior polar cataract at the second time-point $\left(E p h a 2^{+/+}\right.$, median $(\mathrm{IQR})=0.13(0-1.88) ;$ Epha2 ${ }^{+/}$, median $(\mathrm{IQR})=0.25(0-1)$; Table 3 and Fig 3 and 4). There was a significant difference in cataract severity between the exposed and unexposed wild-type mice at this time-point $(p=0.02$, Table 3$)$; a similar difference was not observed between the exposed and unexposed Epha2 $2^{+/-}$mice $(p=0.13$, Table 3). Of the mice exposed to $0.05 \mathrm{~J} / \mathrm{cm}^{2} \mathrm{UV}-\mathrm{B}$, seven out of eight mice of each genotype exhibited anterior polar cataract at the second time-point $\left(E p h a 2^{+/+}\right.$, median $(\mathrm{IQR})=2(1.88-2) ; E p h a 2^{+/-}$, median $(\mathrm{IQR})=1.63(1.38-1.88)$; Table 3 and Fig 3 and 4$)$. The severity of cataract in the exposed mice of each genotype was significantly greater than that in the respective unexposed mice $\left(\right.$ Epha $^{+/+} p<0.001$, Epha2 $^{+/-} p=0.002$, Table 3).

As seen at the first time-point, comparison of anterior polar cataract severity between mice exposed to the lowest and the two higher doses of UV-B at the second time-point, showed a significant difference in severity between $E p h a 2^{+/+}$mice exposed to 0.05 and $0.0125 \mathrm{~J} / \mathrm{cm}^{2}$ UV-B radiation ( $p=0.006$, Table 3). The Epha2 $2^{+/-}$mice exposed to both 0.025 and 0.05 $\mathrm{J} / \mathrm{cm}^{2} \mathrm{UV}-\mathrm{B}$ radiation exhibited significantly more severe cataract than those exposed to $0.0125 \mathrm{~J} / \mathrm{cm}^{2} \mathrm{UV}-\mathrm{B}\left(0.025 \mathrm{~J} / \mathrm{cm}^{2} p=0.027,0.05 \mathrm{~J} / \mathrm{cm}^{2} \mathrm{p}=0.001\right.$; Table 3).

In sixty percent of mice in the study, the second ophthalmic examination was performed four weeks after the last exposure and in the remaining 5-7 weeks after the last exposure. The 
majority of the latter mice were either untreated or treated with the lowest dose of UV-B $\left(0.0125 \mathrm{~J} / \mathrm{cm}^{2}\right)$; only a few mice were treated with 0.025 or $0.05 \mathrm{~J} / \mathrm{cm}^{2} \mathrm{UV}-\mathrm{B}$. Hence variation in the timing of ophthalmic examination is unlikely to be the cause of significant differences in anterior polar cataract severity observed between groups at the second timepoint.

\subsubsection{Effect of genotype and termination time on cataract development in response to}

\section{UV-B exposure}

To determine the effect of Epha2 genotype on susceptibility to anterior polar cataract development following UV-B radiation exposure, cataract severity between $E p h a 2^{+/+}$and Epha2 $^{+/-}$mice exposed to a particular dose of UV-B radiation was compared at each timepoint. No significant difference in severity was observed between the two genotypes of mice exposed to any dose of UV-B radiation at either time-point (Table 3).

Next, to determine the effect of time after termination of UV-B exposure on cataract severity, anterior polar cataract severity in exposed mice of each genotype was compared between time-points. No difference in cataract severity between the two time-points was observed in mice of both the genotypes exposed to 0.0125 and $0.025 \mathrm{~J} / \mathrm{cm}^{2} \mathrm{UV}-\mathrm{B}$ radiation (Fig 5 and data not shown). Wild-type mice exposed to $0.05 \mathrm{~J} / \mathrm{cm}^{2} \mathrm{UV}-\mathrm{B}$ radiation displayed significantly greater cataract severity 4-7 weeks compared to 24-48 hours after termination of

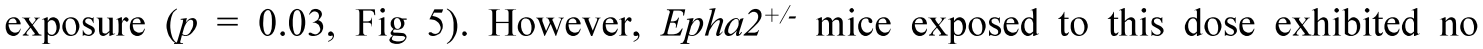
significant difference in cataract severity between the two time points (Fig 5). This suggests that after termination of UV-B exposure cataract severity continues to increase in Epha2 $2^{+/+}$

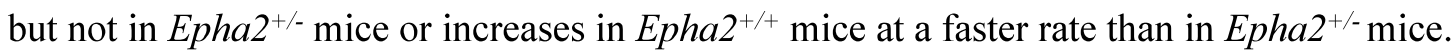




\subsubsection{Structural changes in the lens in response to UV-B exposure}

To determine any structural changes in the lens due to UV-B radiation exposure, histological analysis was performed on lenses of $E p h a 2^{+/+}$and $E p h a 2^{+/-}$mice exposed to 0.025 and 0.05 $\mathrm{J} / \mathrm{cm}^{2} \mathrm{UV}-\mathrm{B}$ radiation. Lenses from mice of both genotypes exposed to $0.025 \mathrm{~J} / \mathrm{cm}^{2} \mathrm{UV}-\mathrm{B}$ radiation showed the presence of vacuoles (white spaces) at the epithelial-fiber cell interface and occasional disruption of the lens epithelium (Fig 6, panels b and e) that were absent in

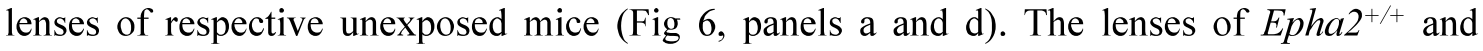
$E p h a 2^{+/-}$mice exposed to $0.05 \mathrm{~J} / \mathrm{cm}^{2} \mathrm{UV}-\mathrm{B}$ radiation exhibited epithelial plaques invaginating into the lens fiber cell mass and disrupting the anterior lens cortex (Fig 6, panels $\mathrm{c}$ and $\mathrm{f}$ ).

Similar plaques were absent in unexposed mice (Fig 6, panels a and d). The equatorial and

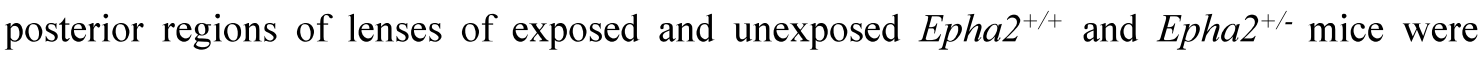
histologically normal (data not shown). The observed histological changes are consistent with the presence of anterior polar cataract in UV-B exposed $E p h a 2^{+/+}$and $E p h a 2^{+/-}$mice and suggestive of epithelial hyperplasia, particularly in mice exposed to the highest dose.

\subsubsection{Mechanism of cataract development in response to UV-B exposure}

$\mathrm{UV}-\mathrm{B}$ radiation exposure reportedly leads to up-regulation of $E P H A 2$ expression in pigmented and non-pigmented cells (Zhang et al., 2008). To determine if UV-B exposure similarly influences Epha2 expression in the lens, Epha2 mRNA levels were compared between lenses of unexposed mice and mice exposed to 0.025 and $0.05 \mathrm{~J} / \mathrm{cm}^{2} \mathrm{UV}-\mathrm{B}$, of each genotype. In both $E p h a 2^{+/+}$and Epha2 $2^{+/-}$mice, similar levels of Epha 2 mRNA were observed in unexposed lenses and lenses exposed to the two doses of UV-B radiation (Fig 7A, third panel and 7B, bottom panel) indicating that Epha2 expression levels in the lens were unchanged 4-7 weeks after exposure.

Furthermore, to determine the mechanism underlying UV-B radiation induced anterior polar 
cataract in mice, involvement of cell proliferation and epithelial-to-mesenchymal transition (EMT) was investigated. For this, expression levels of Mki67 mRNA, a marker of cell proliferation, and Acta2 mRNA, a marker of EMT, were compared between exposed and unexposed lenses of each genotype. Once again, due to low level expression of Mki67 in mouse lens, expression levels were compared by semi-quantitative RT-PCR. Notably, Acta2

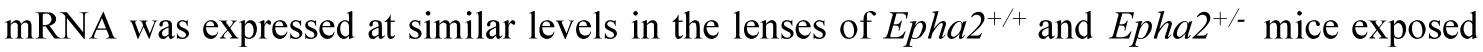
to 0.025 and $0.05 \mathrm{~J} / \mathrm{cm}^{2} \mathrm{UV}-\mathrm{B}$ radiation and lenses of genotype-matched unexposed mice (Fig 7A, second panel and 7B, middle panel). In contrast, Mki67 mRNA was expressed at significantly higher levels in the lenses of $E p h a 2^{+/+}$mice exposed to $0.05 \mathrm{~J} / \mathrm{cm}^{2} \mathrm{UV}-\mathrm{B}$ radiation compared to unexposed mice (Fig $7 \mathrm{~A}$, top panel and $7 \mathrm{~B}$, top panel; $p=0.036$ ). A

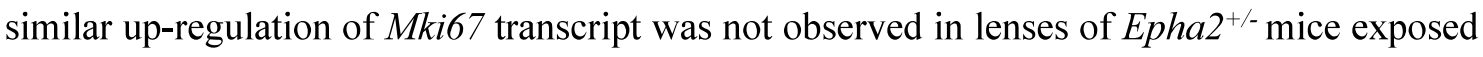
to the same dose of UV-B radiation (Fig 7A, first panel and 7B, top panel). However, a marked increase in Mki67 expression levels could be seen in the lenses of Epha2 ${ }^{+-}$mice exposed to $0.025 \mathrm{~J} / \mathrm{cm}^{2} \mathrm{UV}$-B radiation compared to unexposed mice (Fig 7A, first row). A similar upregulation was not obvious in lenses of Epha2 $2^{+/+}$mice exposed to this dose (Fig 7A, first row). Due to small available sample size, expression levels between unexposed and lenses exposed to $0.025 \mathrm{~J} / \mathrm{cm}^{2}$ of UV-B were not statistically analysed. Taken together, these data suggest that in the present mouse model, cell proliferation underlies anterior polar cataract development in response to UV-B radiation.

\subsection{Discussion}

A complex interaction between environmental stress factors and genetic factors results in the development of age-related cataract. Here we studied interaction of an environmental factor, UV radiation, with a known genetic factor associated with human age-related cataract risk, EPHA2 gene variation, on cataract development, in a mouse model. The interaction was 
investigated in mice carrying a single functional copy of the Epha2 gene instead of mice completely lacking functional Epha2. This study design mimics the human scenario where, unless mutated or deleted, EPHA2 gene is functional. The mice completely lacking functional Epha2 are not appropriate to study the interaction due to complete lack of expression of the gene. It is well accepted that UV-B radiation from sunlight reaching the lens contributes to age-related cataract (Abraham et al., 2006, Cruickshanks et al., 1992, Hayashi et al., 2003). Therefore, in this study, we investigated the effect of UV-B radiation on cataract development. The cumulative effects of repeated exposures to various below-threshold doses of UV-B radiation on cataract formation were investigated to recapitulate repeated exposure of humans to UV radiation from sunlight. In the majority of the reported studies, UV exposure was performed in anesthetized animals in order to better control the dose delivered to the lens (Ayala et al., 2000a, Michael et al., 1998a, Ayala et al., 2000b), and the contralateral eye served as unexposed control. In the present study, we exposed wakeful mice in an attempt to recapitulate UV exposure in humans. It is difficult to estimate the minimum UV-B radiation exposure sufficient to cause cataract in humans primarily because of the difficulty in quantifying daily UV-B exposure of an individual. We observed dose-dependent differences in anterior polar cataract development after repeated exposures to below-

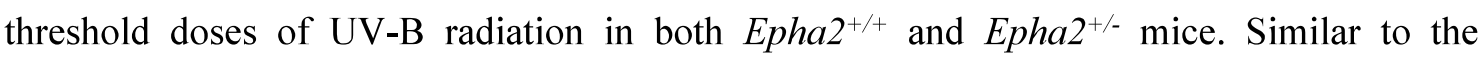
systems developed for grading posterior polar cataract on the basis of lens opacity and its effect on vision in humans (Schroeder, 2005, Singh D. et al., 1993), in the present study, we developed a system for grading anterior polar cataract in mice. Notably, grading by this system is according to the size of lens opacity rather than severity of associated visual impairment. Hence, in the present study, severe anterior polar opacity (grade 3 ) is generally far less severe than that graded by other systems. 
The variation in anterior polar cataract severity observed in both genotypes of mice exposed to a particular dose of UV-B radiation, apart from individual variation, can be attributed to small unavoidable variability in the administered dose (see Section 1.2.4). Similar variation in cataract severity due to unavoidable variability in actual administered dose has been reported in other studies (Meyer et al., 2005). The reported $\mathrm{MTD}_{2.3: 16}$ for $\mathrm{C} 57 \mathrm{Bl} / 6 \mathrm{~J}$ mice is $0.29 \mathrm{~J} / \mathrm{cm}^{2}$ (Meyer et al., 2005). In the present study, cumulative doses of $0.35,0.175$ and $0.0875 \mathrm{~J} / \mathrm{cm}^{2}$ resulting from simple additive effect of multiple exposures to $0.05,0.025$ and $0.0125 \mathrm{~J} / \mathrm{cm}^{2}$ of UV-B, respectively, were administered. We found that both, the cumulative dose above $\left(0.35 \mathrm{~J} / \mathrm{cm}^{2}\right)$ and below $\left(0.175 \mathrm{~J} / \mathrm{cm}^{2}\right)$ the maximum tolerable dose led to anterior polar cataract, which is consistent with the cataract phenotype reported in rodents exposed to UV radiation (Galichanin et al., 2010, Ayala et al., 2000a, Wegener, 1994, Meyer et al., 2005). No significant effect of multiple exposures to $0.0125 \mathrm{~J} / \mathrm{cm}^{2}$ of UV-B radiation in this study suggests that either the dose was too low to initiate any damage in the lens or the damage was rapidly repaired. Histological analysis of lenses of exposed mice further supported the dose-dependent anterior polar cataract severity observed in response to different doses of UV-B radiation. The observed epithelial hyperplasia in lenses of mice exposed to $0.05 \mathrm{~J} / \mathrm{cm}^{2} \mathrm{UV}-\mathrm{B}$ radiation is consistent with previous reports of aberrant cell division of mitotically quiescent lens epithelial cells causing multi-layering under the lens capsule in response to UV-B radiation (Wegener, 1994). More importantly, it correlates with upregulation of the cell proliferation marker, Mki67, in these lenses (Fig 7). The lack of change in Acta2 expression in UV-exposed lenses suggests that the anterior polar cataract induced by repeated exposure to below-threshold doses of UV-B radiation does not involve EMT.

In this study, generally, the Epha2 genotype was not found to have an influence on the magnitude of anterior polar cataract severity in response to any particular dose of UV-B 
radiation at either time-point. A future study with larger group sizes is warranted to discern the effect of allelic deficiency of Epha2 on UV-B induced cataract at a time-point. Interestingly, the period after the final exposure to $0.05 \mathrm{~J} / \mathrm{cm}^{2} \mathrm{UV}-\mathrm{B}$ radiation had differing effects on cataract progression between the two genotypes. Wild-type mice had significantly more severe cataract at the second time-point compared to the first time-point whereas $E p h a 2^{+/-}$mice had similar cataract severity at both the time-points despite showing a trend for higher severity than wild-type mice at the first time-point (Fig 5). Rat lenses exposed to a single dose of $0.5 \mathrm{~J} / \mathrm{cm}^{2}$ of UV-B radiation exhibit similar forward light scattering, 1 week and 32 weeks later (Michael et al., 1996, Meyer et al., 2005). However, the interval between repeated UV-B exposures affects the degree of opacification of rat lens; an interval of 0 or 6 hours between two exposures leads to same degree of opacification whereas an interval of 24 and 48 hours results in increased lenticular damage possibly due to impairment of repair processes (Michael, 2000). In the present study, cataract development at each time-point reflects accumulated damage to the lens from repeated exposures to UV-B radiation. Aggravation of cataract severity in $E p h a 2^{+/+}$mice at the second time-point after exposure to the highest dose of UV-B suggests that lenticular damage continues even after stopping repeated exposures to a below-threshold dose of UV-B radiation. Absence of similar aggravation of severity in Epha2 $2^{+/}$mice suggests less continuing damage to the lens and hence a favourable effect of Epha2 deficiency in the long-term. The difference in exacerbation of cataract severity over time between the two genotypes of mice correlates with significant increase in lens epithelial cell proliferation in wild-type mice indicated by upregulation of Mki67 expression (Fig 7). A trend for higher cataract severity in Epha2 ${ }^{+/}$ mice at the first time-point indicates that time after termination of UV-B exposure may affect the influence of Epha2 deficiency on cataract severity. A larger study including Epha2 ${ }^{-/}$mice is warranted to investigate this effect. 
Apoptosis or necrosis is thought to be the main cause of lenticular damage in rodent lens induced by a single above-threshold dose of UV radiation (Ayala et al., 2007, Galichanin et al., 2012). However, repeated exposures to UV radiation leads to lens epithelial hyperplasia in rodents (Wegener, 1994). Repeated exposure to below-threshold doses of UV radiation also led to lens epithelial hyperplasia, in the present study. Thus, taken together, these studies suggest that the mechanism of cataract development in response to UV radiation depends upon the exposure regimen. Interestingly, UV-B exposure leads to an increase in Epha2 receptor expression in cultured human and murine cells and in turn to cell apoptosis, whereas increased EPHA2 expression in cancer reportedly leads to increased cell proliferation (Zhang et al., 2008). The opposing effect of UV-B exposure on lens epithelial cell fate noted in this study to that reported by Zhang et al. is most likely due to the differences in exposure regimes and time of repair after termination of exposure between the two studies; in the present study cell fate was analysed 4-7 weeks after reported exposure to UV-B compared to 24 hours after a single exposure by Zhang et al. The difference in the model systems used in the two studies may also contribute to the opposite results. Nevertheless, the lens epithelial cell hyperplasia due to increased cell proliferation observed in lenses of mice exposed to $0.05 \mathrm{~J} / \mathrm{cm}^{2} \mathrm{UV}-\mathrm{B}$ in this study was not accompanied by an increase in Epha2 expression (Fig 7). Hence, a different mechanism may underlie the observed lens epithelial hyperplasia. Future research is warranted to determine the mechanism of hyperplasia underlying the cataract induced by repeated exposure to below-threshold doses of UV-B radiation in mice.

\subsection{Conclusion}

In conclusion, to the best of our knowledge, this is the first study to demonstrate the effect of repeated exposures to below-threshold doses of UV-B radiation on cataract development in an Epha2 knockout mouse model. The findings demonstrate a dose-dependent effect of UV- 
$\mathrm{B}$ radiation on anterior polar cataract development, and indicate a likely favourable effect of

Epha2 deficiency against progression of UV radiation-induced cataract over time in mice.

\subsection{Acknowledgements}

We thank Ms Rebecca Hamilton for assistance with animal handling and care for this study.

\subsection{References}

ABRAHAM, A. G., CONDON, N. G. \& WEST GOWER, E. 2006. The new epidemiology of cataract. Ophthalmol Clin North Am, 19, 415-25.

ABRAHAM, A. G., COX, C. \& WEST, S. 2010. The differential effect of ultraviolet light exposure on cataract rate across regions of the lens. Invest Ophthalmol Vis Sci, 51, 3919-23.

ALIZADEH, A., CLARK, J., SEEBERGER, T., HESS, J., BLANKENSHIP, T. \& FITZGERALD, P. G. 2004. Characterization of a mutation in the lens-specific CP49 in the 129 strain of mouse. Invest Ophthalmol Vis Sci, 45, 884-91.

AYALA, M., STRID, H., JACOBSSON, U. \& SODERBERG, P. G. 2007. p53 expression and apoptosis in the lens after ultraviolet radiation exposure. Invest Ophthalmol Vis Sci, 48, 4187-91.

AYALA, M. N., MICHAEL, R. \& SODERBERG, P. G. 2000a. In vivo cataract after repeated exposure to ultraviolet radiation. Exp Eye Res, 70, 451-6.

AYALA, M. N., MICHAEL, R. \& SODERBERG, P. G. 2000b. Influence of exposure time for UV radiation-induced cataract. Invest Ophthalmol Vis Sci, 41, 3539-43.

BHAGYALAXMI, S. G., SRINIVAS, P., BARTON, K. A., KUMAR, K. R., VIDYAVATHI, M., PETRASH, J. M., BHANUPRAKASH REDDY, G. \& PADMA, T. 2009. A novel mutation (F71L) in alphaA-crystallin with defective chaperone-like function associated with age-related cataract. Biochim Biophys Acta, 1792, 974-81.

CHENG, C., ANSARI, M. M., COOPER, J. A. \& GONG, X. 2013. EphA2 and Src regulate equatorial cell morphogenesis during lens development. Development, 140, 4237-45.

CHYLACK, L. T., JR., WOLFE, J. K., SINGER, D. M., LESKE, M. C., BULLIMORE, M. A., BAILEY, I. L., FRIEND, J., MCCARTHY, D. \& WU, S. Y. 1993. The Lens Opacities Classification System III. The Longitudinal Study of Cataract Study Group. Arch Ophthalmol, 111, 831-6.

CRUICKSHANKS, K. J., KLEIN, B. E. \& KLEIN, R. 1992. Ultraviolet light exposure and lens opacities: the Beaver Dam Eye Study. American journal of public health, 82, 1658-1662.

DAVE, A., LAURIE, K., STAFFIERI, S. E., TARANATH, D., MACKEY, D. A., MITCHELL, P., WANG, J. J., CRAIG, J. E., BURDON, K. P. \& SHARMA, S. 2013. Mutations in the EPHA2 gene are a major contributor to inherited cataracts in SouthEastern Australia. PLoS One, 8, e72518.

DELCOURT, C., CARRIERE, I., PONTON-SANCHEZ, A., LACROUX, A., COVACHO, M.-J. \& PAPOZ, L. 2000. Light exposure and risk of cortical, nuclear and posterior 
subcapsular cataracts. The Pathologies Oculaires Liees a I' Age (POLA) Study. Archives of Ophthalmology, 118, 385-392.

DILLON, J., ZHENG, L., MERRIAM, J. C. \& GAILLARD, E. R. 1999. The optical properties of the anterior segment of the eye: implications for cortical cataract. Exp Eye Res, 68, 785-95.

GALICHANIN, K., LOFGREN, S., BERGMANSON, J. \& SODERBERG, P. 2010. Evolution of damage in the lens after in vivo close to threshold exposure to UV-B radiation: cytomorphological study of apoptosis. Exp Eye Res, 91, 369-77.

GALICHANIN, K., LOFGREN, S. \& SODERBERG, P. 2014. Cataract after repeated daily in vivo exposure to ultraviolet radiation. Health Phys, 107, 523-9.

GALICHANIN, K., SVEDLUND, J. \& SODERBERG, P. 2012. Kinetics of GADD45alpha, TP53 and CASP3 gene expression in the rat lens in vivo in response to exposure to double threshold dose of UV-B radiation. Exp Eye Res, 97, 19-23.

HAYASHI, L. C., HAYASHI, S., YAMAOKA, K., TAMIYA, N., CHIKUDA, M. \& YANO, E. 2003. Ultraviolet B exposure and type of lens opacity in ophthalmic patients in Japan. Sci Total Environ, 302, 53-62.

JUN, G., GUO, H., KLEIN, B. E., KLEIN, R., WANG, J. J., MITCHELL, P., MIAO, H., LEE, K. E., JOSHI, T., BUCK, M., CHUGHA, P., BARDENSTEIN, D., KLEIN, A. P., BAILEY-WILSON, J. E., GONG, X., SPECTOR, T. D., ANDREW, T., HAMMOND, C. J., ELSTON, R. C., IYENGAR, S. K. \& WANG, B. 2009. EPHA2 is associated with age-related cortical cataract in mice and humans. PLoS Genet, 5, e1000584.

KARAS, N., GOBEC, L., PFEIFER, V., MLINAR, B., BATTELINO, T. \& LUKACBAJALO, J. 2003. Mutations in galactose-1-phosphate uridyltransferase gene in patients with idiopathic presenile cataract. $J$ Inherit Metab Dis, 26, 699-704.

KATOH, N., JONASSON, F., SASAKI, H., KOJIMA, M., ONO, M., TAKAHASHI, N. \& SASAKI, K. 2001. Cortical lens opacification in Iceland. Risk factor analysis -Reykjavik Eye Study. Acta Ophthalmol Scand, 79, 154-9.

KAUL, H., RIAZUDDIN, S. A., SHAHID, M., KOUSAR, S., BUTT, N. H., ZAFAR, A. U., KHAN, S. N., HUSNAIN, T., AKRAM, J., HEJTMANCIK, J. F. \& RIAZUDDIN, S. 2010. Autosomal recessive congenital cataract linked to EPHA2 in a consanguineous Pakistani family. Mol Vis, 16, 511-7.

LEE, C. M. \& AFSHARI, N. A. 2017. The global state of cataract blindness. Curr Opin Ophthalmol, 28, 98-103.

LEIGHTON, P. A., MITCHELL, K. J., GOODRICH, L. V., LU, X., PINSON, K., SCHERZ, P., SKARNES, W. C. \& TESSIER-LAVIGNE, M. 2001. Defining brain wiring patterns and mechanisms through gene trapping in mice. Nature, 410, 174-9.

LIAO, J., SU, X., CHEN, P., WANG, X., XU, L., LI, X., THEAN, L., TAN, C., TAN, A. G., TAY, W. T., JUN, G., ZHENG, Y., CHEW, M., WANG, Y. X., TAN, Q. S., BARATHI, V. A., KLEIN, B. E., SAW, S. M., VITHANA, E. N., TAI, E. S., IYENGAR, S. K., MITCHELL, P., KHOR, C. C., AUNG, T., WANG, J. J., JONAS, J. B., TEO, Y. Y., WONG, T. Y. \& CHENG, C. Y. 2014. Meta-analysis of genomewide association studies in multiethnic Asians identifies two loci for age-related nuclear cataract. Hum Mol Genet, 23, 6119-28.

LUCAS, R. M. 2011. An epidemiological perspective of ultraviolet exposure--public health concerns. Eye Contact Lens, 37, 168-75.

MAMATA, M., SRIDHAR, G., REDDY, K. R., NAGARAJU, T. \& PADMA, T. 2011. Is the variant c.422+90G --> A in intron 4 of indoleamine 2, 3 -dioxygenase (IDO) gene related to age related cataracts? Mol Vis, 17, 1203-8. 
MCCARTY, C. A., NANJAN, M. B. \& TAYLOR, H. R. 2000. Attributable risk estimates for cataract to prioritize medical and public health action. Invest Ophthalmol Vis Sci, 41, 3720-5.

MCCARTY, C. A. \& TAYLOR, H. R. 2002. A Review of the Epidemiologic evidence linking Ultraviolet radiation and Cataracts. Developments in Ophthalmology, 35, 2131.

MEYER, L. M., DONG, X., WEGENER, A. \& SODERBERG, P. 2008. Dose dependent cataractogenesis and Maximum Tolerable Dose (MTD(2.3:16)) for UVR $300 \mathrm{~nm}-$ induced cataract in C57BL/6J mice. Exp Eye Res, 86, 282-9.

MEYER, L. M., SODERBERG, P., DONG, X. \& WEGENER, A. 2005. UVR-B induced cataract development in C57 mice. Exp Eye Res, 81, 389-94.

MICHAEL, R. 2000. Development and repair of cataract induced by ultraviolet radiation. Ophthalmic Res, 32 Suppl 1, ii-iii; 1-44.

MICHAEL, R. \& BRISMAR, H. 2001. Lens growth and protein density in the rat lens after in vivo exposure to ultraviolet radiation. Invest Ophthalmol Vis Sci, 42, 402-8.

MICHAEL, R., SODERBERG, P. G. \& CHEN, E. 1996. Long-term development of lens opacities after exposure to ultraviolet radiation at $300 \mathrm{~nm}$. Ophthalmic Res, 28, 20918.

MICHAEL, R., SODERBERG, P. G. \& CHEN, E. 1998a. Dose-response function for lens forward light scattering after in vivo exposure to ultraviolet radiation. Graefes Arch Clin Exp Ophthalmol, 236, 625-9.

MICHAEL, R., VRENSEN, G. F., VAN MARLE, J., GAN, L. \& SODERBERG, P. G. 1998b. Apoptosis in the rat lens after in vivo threshold dose ultraviolet irradiation. Invest Ophthalmol Vis Sci, 39, 2681-7.

MICHAEL, R., VRENSEN, G. F., VAN MARLE, J., LOFGREN, S. \& SODERBERG, P. G. 2000. Repair in the rat lens after threshold ultraviolet radiation injury. Invest Ophthalmol Vis Sci, 41, 204-12.

MITCHELL, K. J., PINSON, K. I., KELLY, O. G., BRENNAN, J., ZUPICICH, J., SCHERZ, P., LEIGHTON, P. A., GOODRICH, L. V., LU, X., AVERY, B. J., TATE, P., DILL, K., PANGILINAN, E., WAKENIGHT, P., TESSIER-LAVIGNE, M. \& SKARNES, W. C. 2001. Functional analysis of secreted and transmembrane proteins critical to mouse development. Nat Genet, 28, 241-9.

MODENESE, A., KORPINEN, L. \& GOBBA, F. 2018. Solar Radiation Exposure and Outdoor Work: An Underestimated Occupational Risk. Int J Environ Res Public Health, 15.

NHMRC;. 2004. Australian code of practice for the care and use of animals for scientific purposes [Online]. Available: https://www.nhmrc.gov.au/guidelines/publications/ea28 [Accessed Sept 17 2014].

PADMA, G., MAMATA, M., REDDY, K. R. \& PADMA, T. 2011. Polymorphisms in two DNA repair genes (XPD and XRCC1)--association with age related cataracts. $\mathrm{Mol}$ Vis, 17, 127-33.

PASQUALE, E. B. 2008. Eph-ephrin bidirectional signaling in physiology and disease. Cell, $133,38-52$.

ROBERTS, J. E. 2011. Ultraviolet radiation as a risk factor for cataract and macular degeneration. Eye Contact Lens, 37, 246-9.

SANDILANDS, A., WANG, X., HUTCHESON, A. M., JAMES, J., PRESCOTT, A. R., WEGENER, A., PEKNY, M., GONG, X. \& QUINLAN, R. A. 2004. Bfsp2 mutation found in mouse 129 strains causes the loss of CP49' and induces vimentin-dependent changes in the lens fibre cell cytoskeleton. Exp Eye Res, 78, 875-89. 
SCHROEDER, H. W. 2005. The management of posterior polar cataract: the role of patching and grading. Strabismus, 13, 153-6.

SHENTU, X. C., ZHAO, S. J., ZHANG, L. \& MIAO, Q. 2013. A novel p.R890C mutation in EPHA2 gene associated with progressive childhood posterior cataract in a Chinese family. Int J Ophthalmol, 6, 34-8.

SHI, Y., DE MARIA, A., BENNETT, T., SHIELS, A. \& BASSNETT, S. 2012. A Role for Epha2 in Cell Migration and Refractive Organization of the Ocular Lens. Invest Ophthalmol Vis Sci, 53, 551-9.

SHI, Y., SHI, X., JIN, Y., MIAO, A., BU, L., HE, J., JIANG, H., LU, Y., KONG, X. \& HU, L. 2008. Mutation screening of HSF4 in 150 age-related cataract patients. Mol Vis, 14, 1850-5.

SHIELS, A., BENNETT, T. M., KNOPF, H. L., MARAINI, G., LI, A., JIAO, X. \& HEJTMANCIK, J. F. 2008. The EPHA2 gene is associated with cataracts linked to chromosome 1p. Mol Vis, 14, 2042-55.

SHIELS, A. \& HEJTMANCIK, J. F. 2007. Genetic origins of cataract. Arch Ophthalmol, $125,165-73$.

SINGH D., WORST J., SINGH R. \& I.R., S. 1993. Cataract and IOL. New Delhi, India: Jaypee Brothers Medical Publishers.

SODERBERG, P. G. 1990. Experimental cataract induced by ultraviolet radiation. Acta Ophthalmol Suppl, 1-75.

SODERBERG, P. G., LOFGREN, S., AYALA, M., DONG, X., KAKAR, M. \& MODY, V. 2002. Toxicity of ultraviolet radiation exposure to the lens expressed by maximum tolerable dose. Dev Ophthalmol, 35, 70-5.

SPARROW, J. M., BRON, A. J., BROWN, N. A., AYLIFFE, W. \& HILL, A. R. 1986. The Oxford Clinical Cataract Classification and Grading System. Int Ophthalmol, 9, 20725.

SUNDARESAN, P., RAVINDRAN, R. D., VASHIST, P., SHANKER, A., NITSCH, D., TALWAR, B., MARAINI, G., CAMPARINI, M., NONYANE, B. A., SMEETH, L., CHAKRAVARTHY, U., HEJTMANCIK, J. F. \& FLETCHER, A. E. 2012. EPHA2 Polymorphisms and Age-Related Cataract in India. PLoS One, 7, e33001.

TAYLOR, H. R., WEST, S. K., ROSENTHAL, F. S., MUNOZ, B., NEWLAND, H. S., ABBEY, H. \& EMMET, E. A. 1988. Effect of ultraviolet radiation on cataract formation. The New England journal of medicine, 319, 1429-1433.

TEAM, R. C. 2013. R: A language and environment for statistical computing. [Online]. Vienna, Austria. Available: http://www.R-project.org/ [Accessed].

WEGENER, A. R. 1994. In vivo studies on the effect of UV-radiation on the eye lens in animals. Doc Ophthalmol, 88, 221-32.

WEST, S. K., DUNCAN, D. D., MUNOZ, B., RUBIN, G. S., FRIED, L. P., BANDEENROCHE, K. \& SCHEIN, O. D. 1998. Sunlight exposure and risk of lens opacities in a population-based study: the Salisbury Eye Evaluation project. JAMA, 280, 714-8.

WEST, S. K. \& VALMADRID, C. T. 1995. Epidemiology of risk factors for age-related cataract. Surv Ophthalmol, 39, 323-34.

ZHANG, G., NJAUW, C. N., PARK, J. M., NARUSE, C., ASANO, M. \& TSAO, H. 2008. EphA2 is an essential mediator of UV radiation-induced apoptosis. Cancer Res, 68, 1691-6.

ZHANG, T., HUA, R., XIAO, W., BURDON, K. P., BHATTACHARYA, S. S., CRAIG, J. E., SHANG, D., ZHAO, X., MACKEY, D. A., MOORE, A. T., LUO, Y., ZHANG, J. \& ZHANG, X. 2009. Mutations of the EPHA2 receptor tyrosine kinase gene cause autosomal dominant congenital cataract. Hum Mutat, 30, E603-11. 
ZHANG, Y., ZHANG, L., SUN, D., LI, Z., WANG, L. \& LIU, P. 2011. Genetic polymorphisms of superoxide dismutases, catalase, and glutathione peroxidase in agerelated cataract. Mol Vis, 17, 2325-32. 


\section{Fig 1: Anterior polar cataract grading system used in this study.}

Representative images of cross-section illumination of the lens showing no cataract, and grades 1-3 anterior polar cataract in mice as indicated. UV-B exposure of mice resulted in anterior polar cataract (see Section 1.2.4). Each image from left to right shows a cross-section of the cornea (thick bright arc), anterior chamber (dark region) and lens (narrow dim arc). Iris (brown pigment) is visible at the upper and/or lower end of the lens in each image. Anterior polar cataract (bright spot) in the lens is indicated by an arrow. Note the increasing size of cataract from grade 1 to 3 . This grading system was used to monitor anterior polar cataract development following UV-B exposure.

\section{Fig 2: Epha2 expression in wild-type and Epha2 knockout mouse lenses.}

Expression levels of Epha2 mRNA were analysed in lenses of two-month-old Epha2 ${ }^{+/+}$, Epha2 $^{+/-}$ and Epha2 $2^{--}$lenses by semi-quantitative RT-PCR. Expression was analysed in lenses of three animals per genotype; $B 2 m$ mRNA was amplified as housekeeping control. The amplified Epha2 and $B 2 m$ specific products of the expected sizes (265 bp and $193 \mathrm{bp}$, respectively) can be seen as indicated. Numbers above each panel indicate independent animals and correspond between panels. Numbers on the left refer to size of molecular standards (M). RT', no reverse transcription control; $\mathrm{C}^{-}$, no template control.

\section{Fig 3: UV-B induced anterior polar cataract in $E p h a 2^{+/+}$and $E p h a 2^{+/-}$mice.}

Five-week-old Epha2 $2^{+/+}$(WT) and Epha2 $2^{+/}$(HET) mice were repeatedly exposed to $0.0125,0.025$ or $0.05 \mathrm{~J} / \mathrm{cm}^{2}$ of UV-B radiation and ophthalmic examination performed 24-48 hours and 4-7 weeks after the last exposure, as indicated. Unexposed mice of each genotype served as controls. 
Anterior polar cataract was absent in unexposed mice (panels a, e, i, m) and in Epha2 $2^{+/+}$and Epha2 $2^{+/-}$mice exposed to $0.0125 \mathrm{~J} / \mathrm{cm}^{2} \mathrm{UV}-\mathrm{B}$ radiation (panels $\mathrm{b}, \mathrm{f}, \mathrm{j}, \mathrm{n}$ ). Distinct anterior polar cataract could be seen in Epha2 $2^{+/+}$and $E p h a 2^{+/-}$mice exposed to 0.025 (arrow, panels c, g, k, o) and $0.05 \mathrm{~J} / \mathrm{cm}^{2}$ (arrow, panels $\mathrm{d}, \mathrm{h}, 1, \mathrm{p}$ ) UV-B radiation at both the time-points. Slit-lamp microscopy images of eyes of representative animals from each experimental group are shown.

Fig 4: Distribution of anterior polar cataract grading data in unexposed and UV-B exposed $\operatorname{Epha2}^{+/+}$and Epha2 ${ }^{+/-}$mice.

Scatter plots showing the distribution of average anterior polar cataract grades in unexposed and UV-B exposed Epha2 $2^{+/+}$(WT, left panels) and Epha2 $2^{+/-}$(HET, right panels) mice 24-48 hours (top panels) and 4-7 weeks (bottom panels) after the final exposure ( $\mathrm{n}=8$ per group). X-axis, UV-B dose in $\mathrm{J} / \mathrm{cm}^{2} ; \mathrm{y}$-axis, average anterior polar cataract grade in the two eyes. Each circle represents average cataract grade in an animal. Note the UV-B dose-dependent increase in the numbers of animals with cataract and increase in cataract severity in each panel. Also note the increase in the number of animals with cataract and increase in cataract severity at the second compared to the first time-point in WT (left panels) and HET (right panels) mice exposed to $0.05 \mathrm{~J} / \mathrm{cm}^{2}$ of UV-B

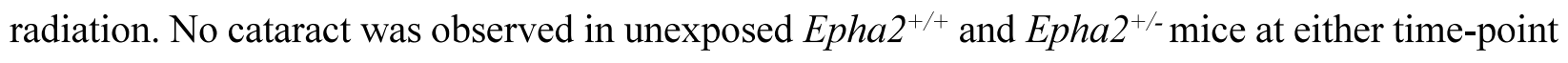

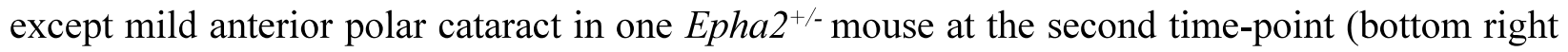
panel).

Fig 5: Comparison of anterior polar cataract severity in $\operatorname{Epha2}^{+/+}$and $\mathrm{Epha2}^{+/-}$mice exposed to the two highest doses of UV-B radiation. 
The plot shows average anterior polar cataract grades in $\mathrm{Epha}^{+/+}$(WT) and $\mathrm{Epha2}^{+/-}$(HET) mice 24-48 hours and 4-7 weeks after termination of repeated exposure to 0.025 or $0.05 \mathrm{~J} / \mathrm{cm}^{2} \mathrm{UV}-\mathrm{B}$ radiation ( $\mathrm{n}=8$ per group). $\mathrm{X}$-axis, $\mathrm{UV}-\mathrm{B}$ dose in $\mathrm{J} / \mathrm{cm}^{2}$ and time; $\mathrm{y}$-axis, average anterior polar cataract grade in both eyes of animals in a group. No significant difference in cataract severity was observed between $E p h a 2^{+/+}$and Epha2 $2^{+/}$mice exposed to either dose of UV-B at either timepoint. In Epha2 $2^{+/+}$mice exposed to $0.05 \mathrm{~J} / \mathrm{cm}^{2} \mathrm{UV}-\mathrm{B}$, cataract severity had significantly increased at the second time-point compared to the first-time point (Wilcoxon Signed Rank test; $p=0.03$ ). A similar increase in severity between time-points was not noted in Epha2 $2^{+/}$mice exposed to 0.05 $\mathrm{J} / \mathrm{cm}^{2}$ of UV-B radiation. Error bars indicate standard error of the mean.

\section{Fig 6: Histological analysis of unexposed and UV-B exposed mouse lenses.}

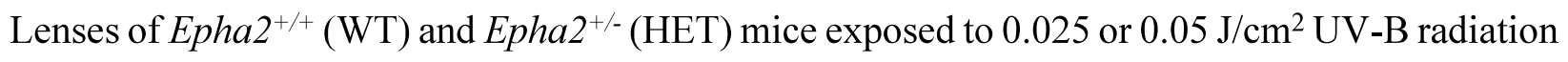
and unexposed (untreated) mice were analysed by hematoxylin and eosin staining after the second ophthalmic examination. Sections from the pupillary region of each lens are shown. The dose of UV-B radiation and Epha2 genotype are as indicated. Hematoxylin stained nuclei (blue) and eosin stained cytoplasm (pink) of lens epithelial cells and of lens fiber cells can be seen. Cornea is visible in some sections (panels $\mathrm{a}, \mathrm{b}$ and $\mathrm{d}$ ). Unexposed mice of both genotypes showed normal lens architecture (panels a and d). Vacuoles and occasional disruption of the lens epithelium could be seen at the epithelial-fiber cell interface (arrow and inset, panels b and e) in the lenses of each genotype of mice exposed to $0.025 \mathrm{~J} / \mathrm{cm}^{2} \mathrm{UV}-\mathrm{B}$ radiation. Lenses of Epha2 ${ }^{+/+}$and $E p h a 2^{+/-}$mice exposed to $0.05 \mathrm{~J} / \mathrm{cm}^{2} \mathrm{UV}-\mathrm{B}$ showed aberrant lens epithelial cell growth (arrow, panels $\mathrm{c}$ and $\mathrm{f}$ ) and disruption of the underlying fiber cell arrangement. A relatively thinner lens capsule in some 
sections is an artefact due to folded section. Representative images of lenses of three mice per group are shown. Scale-bar $50 \mu \mathrm{m}$.

Fig 7. Relative expression of Epha2 gene and markers of cell proliferation and EMT in UV-B exposed and unexposed mouse lenses.

A. mRNA levels of Epha2 gene, cell proliferation marker Mki67 and EMT marker Acta2 in lenses

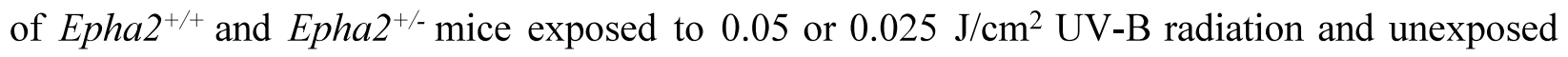
(0.0) mice were analysed by semi-quantitative RT-PCR. Analysis was performed 4-7 weeks after termination of exposure. $B 2 \mathrm{~m}$ mRNA expression was used as the housekeeping control. Each lane represents amplification in pooled lenses of two mice of the same gender; lanes 1 and 2 indicate two independent pools. The amplified Mki67, Acta2, Epha2 and B2m specific products of the expected sizes (490 bp, 338 bp, 265 bp and 193 bp, respectively) can be seen as indicated. Numbers on the left refer to size of molecular standards (M). RT-, no reverse transcription control. B. Relative quantification of Mki67 (top), Acta2 (middle) and Epha2 (bottom) specific amplification products between $0.05 \mathrm{~J} / \mathrm{cm}^{2} \mathrm{UV}-\mathrm{B}$ radiation exposed and unexposed (0.0) lenses of Epha2 $2^{+/+}$and $E p h a 2^{+/-}$ mice, shown in A. Mean expression of each gene was normalized to $B 2 m$ mRNA levels. Data was analysed using two-tailed Student's $t$-test and significant $p$ value indicated. Error bars represent standard deviation of the mean. 
Grade 0

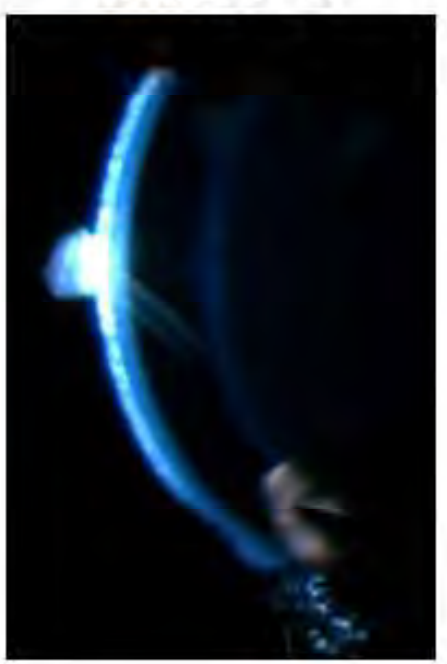

Grade 1

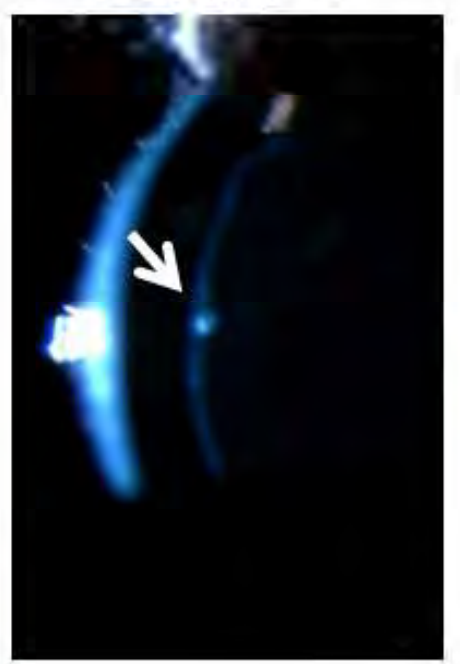

Grade 2

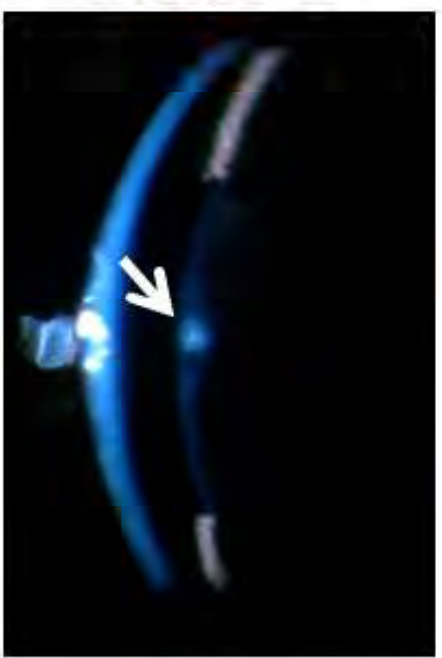

Grade 3

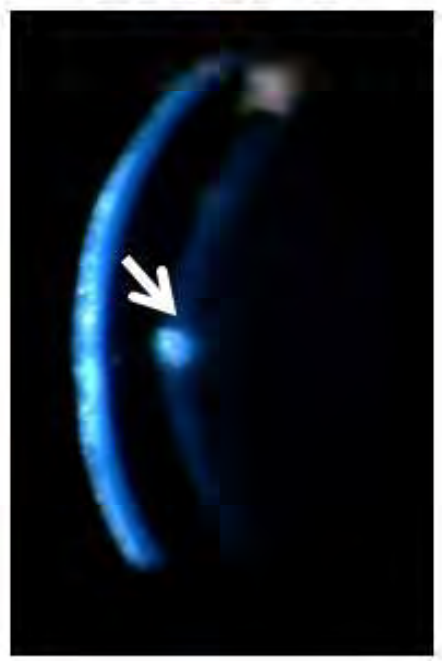




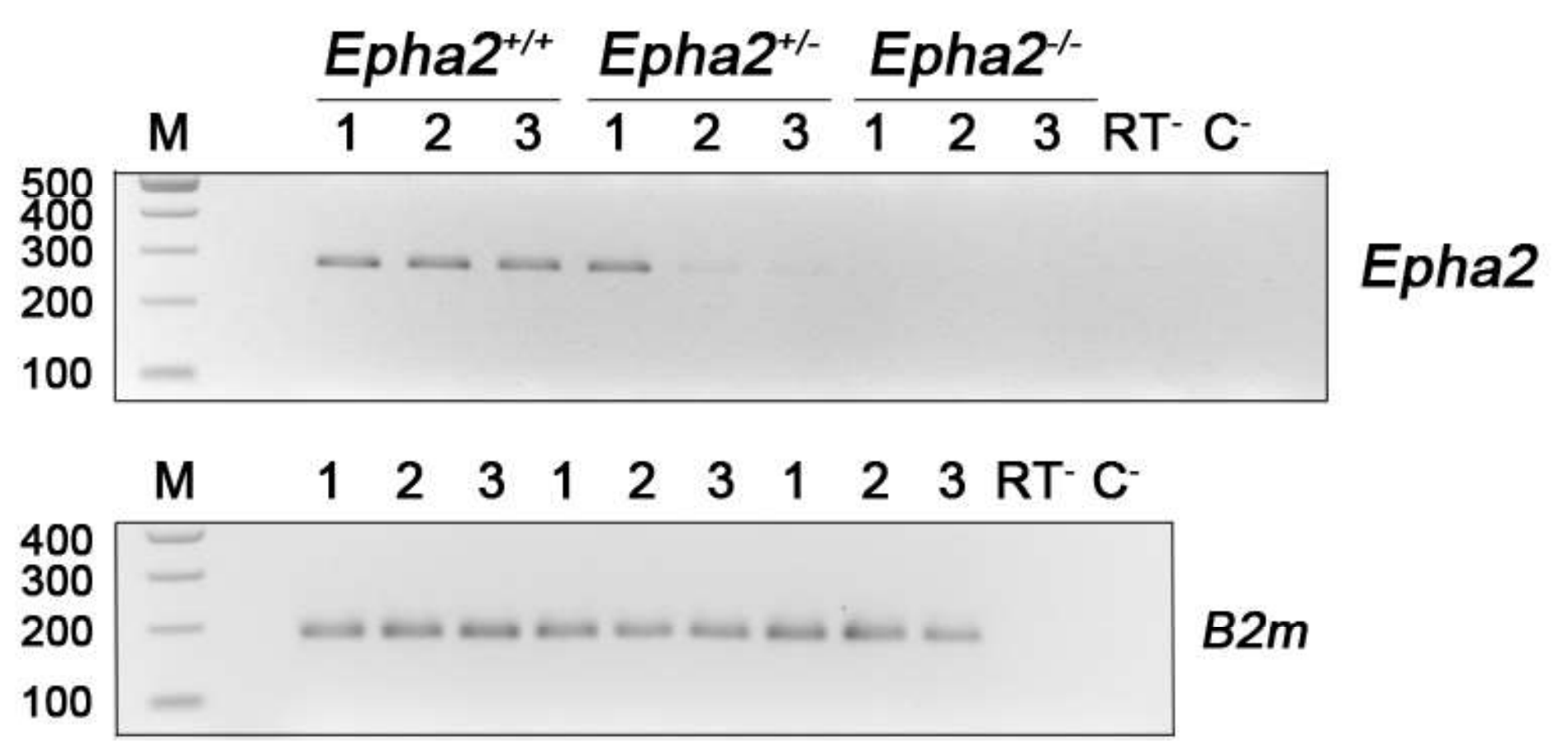




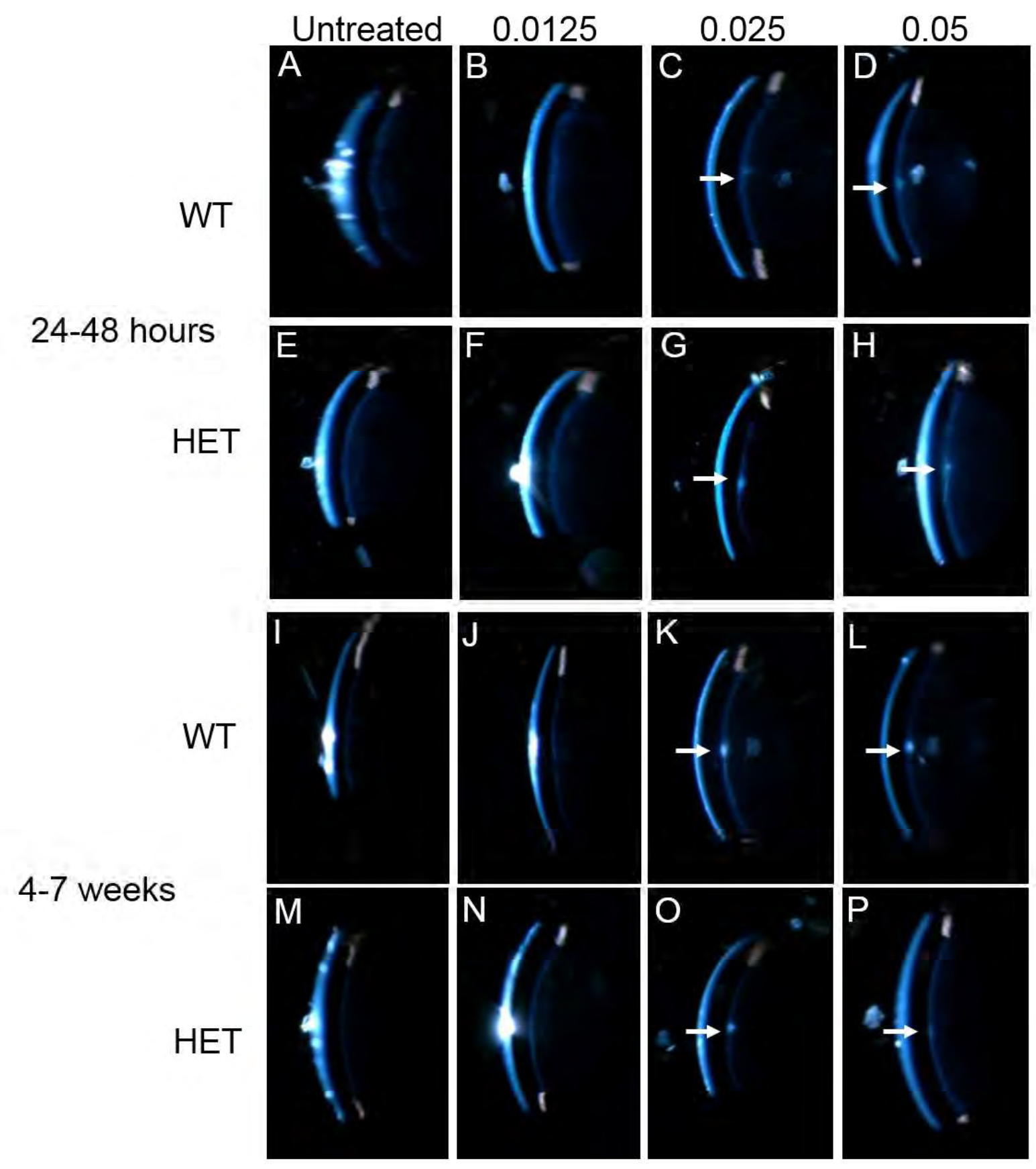


24-48 hours after UV-B treatment
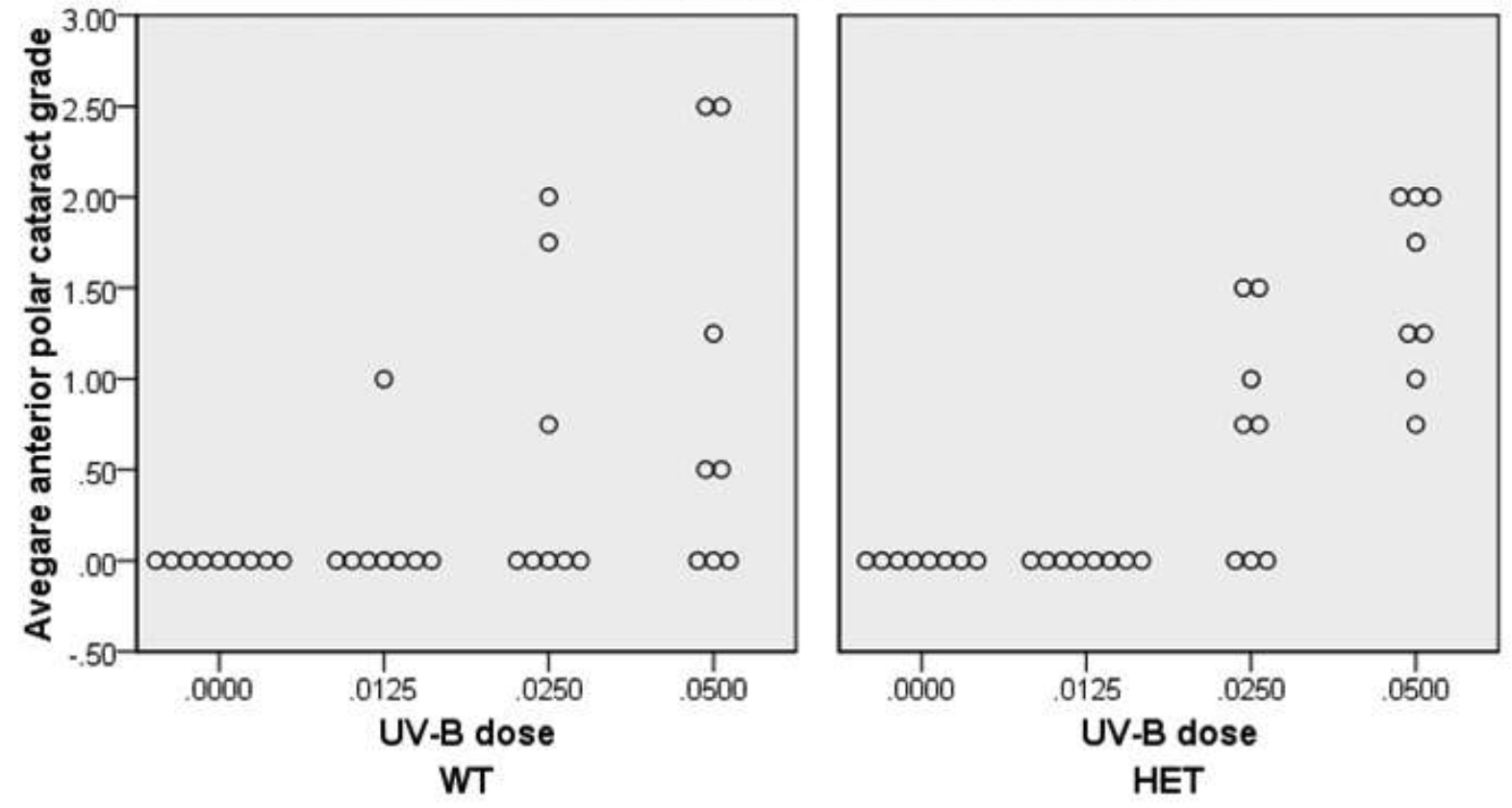

4-7 weeks after UV-B treatment
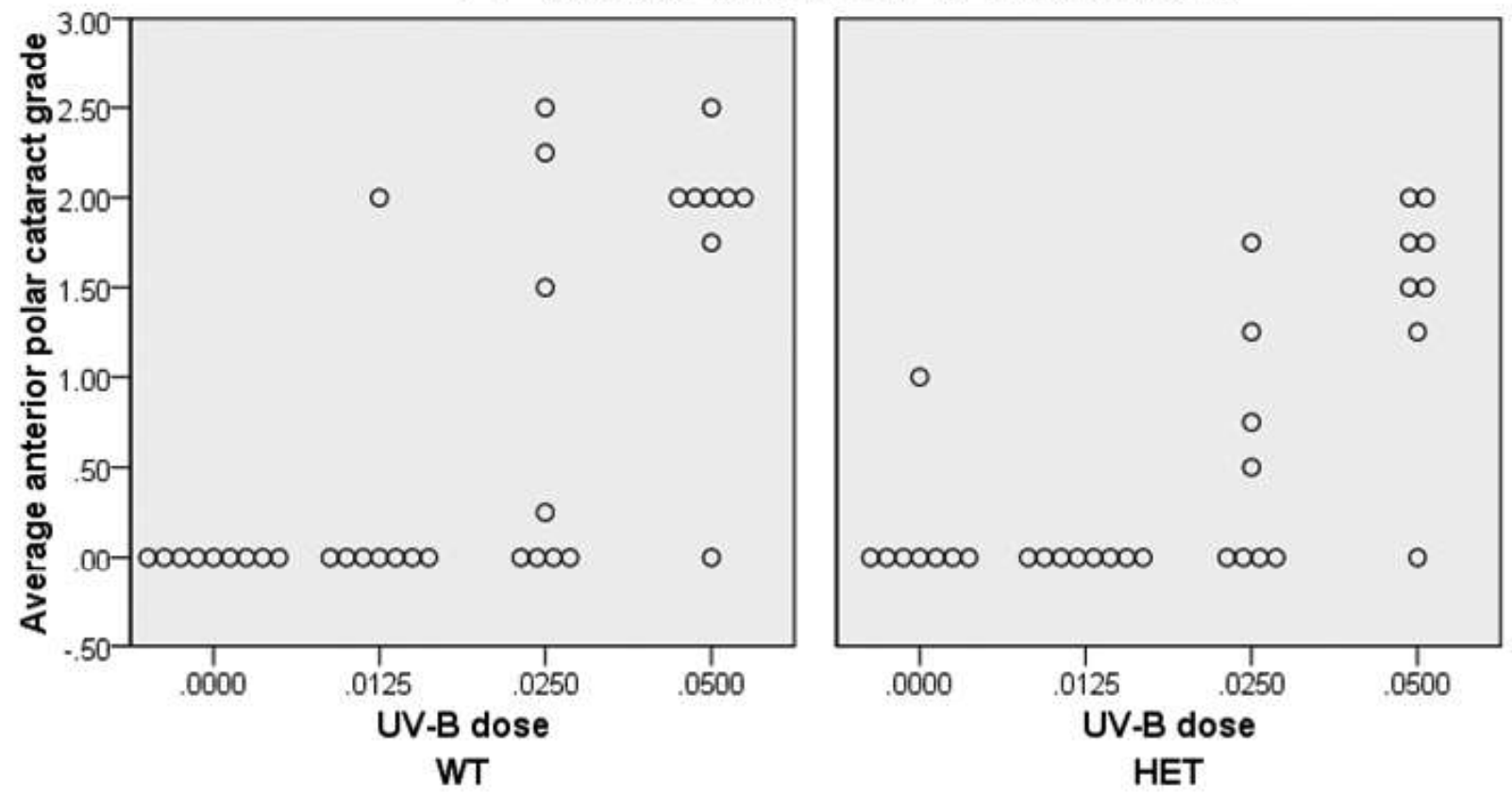


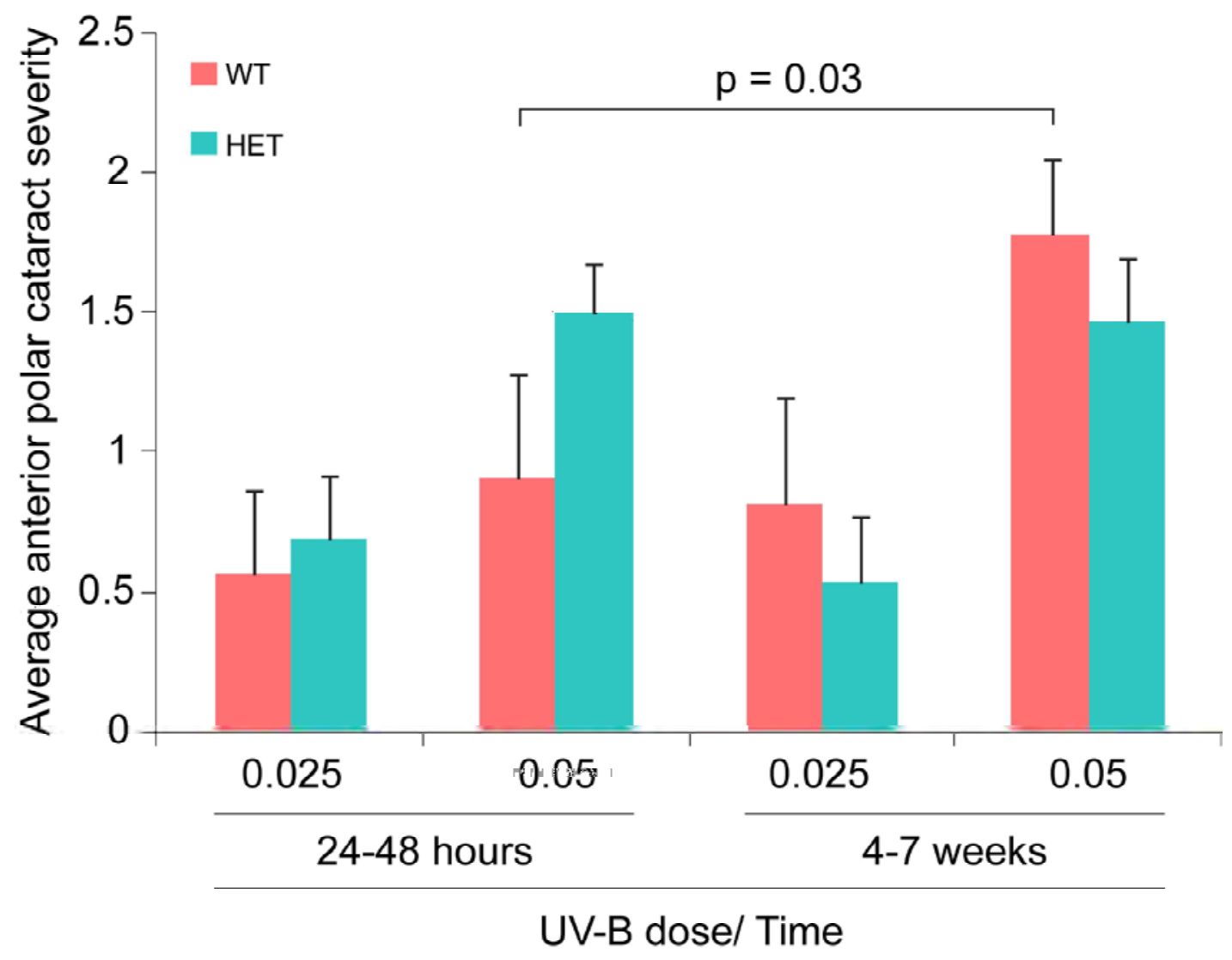



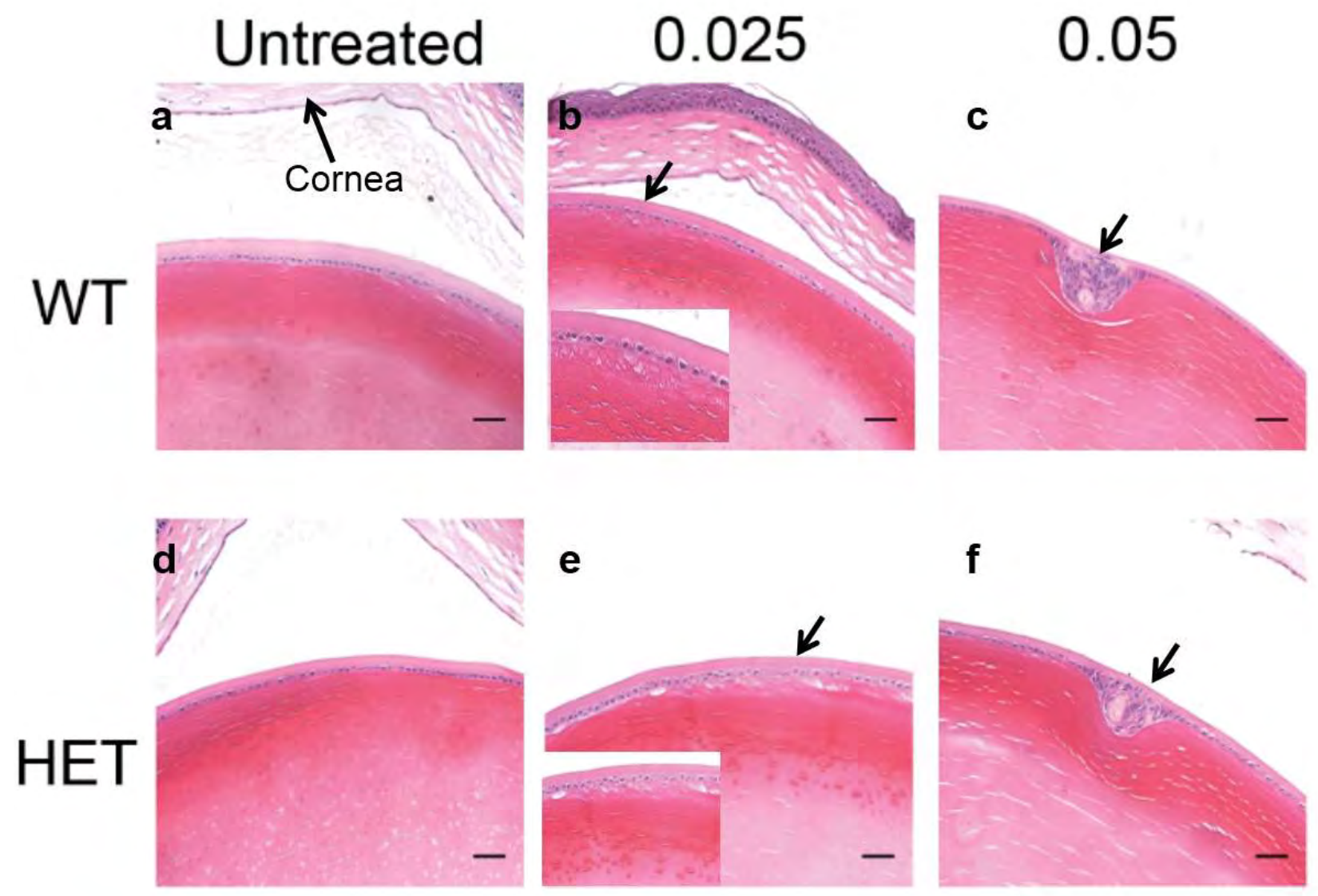

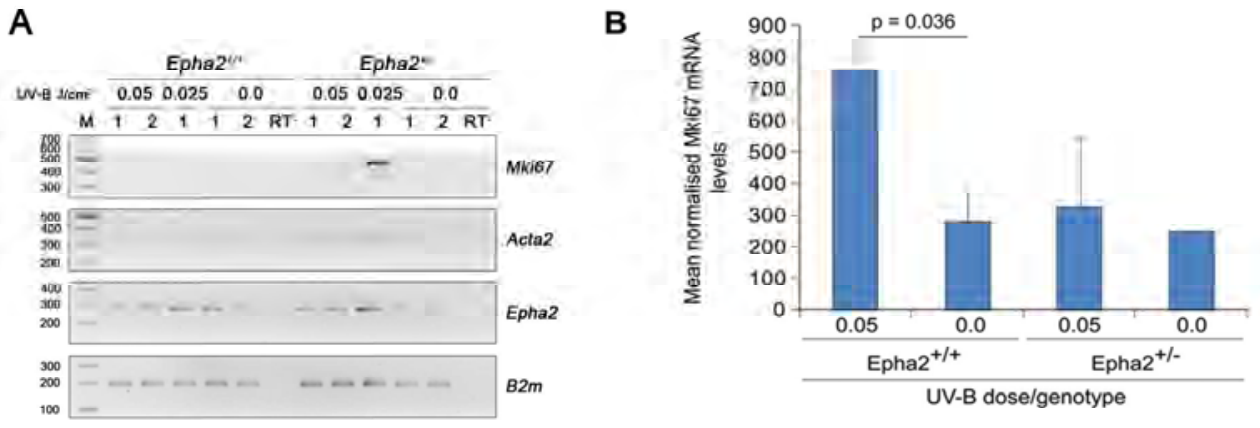

UV-B dose/genotype
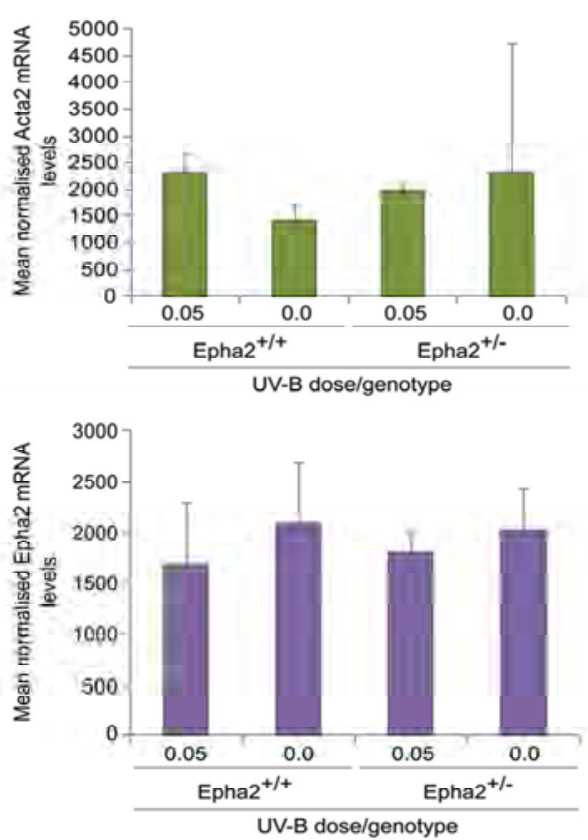